The Journal of Agricultural Science

cambridge.org/ags

\section{Crops and Soils Review}

*Present address: 12466 Montego Plaza, Dallas, TX 75230, USA.

Cite this article: Bottrell DG, Schoenly KG (2018). Integrated pest management for resource-limited farmers: challenges for achieving ecological, social and economic sustainability. The Journal of Agricultural Science 156, 408-426. https://doi.org/10.1017/ S0021859618000473

Received: 27 July 2017

Revised: 29 April 2018

Accepted: 29 May 2018

First published online: 27 June 2018

Key words:

Agrobiodiversity; agroecosystems; developing countries; integrated pest management; sustainable agriculture

Author for correspondence:

K.G. Schoenly, E-mail: kschoenly@csustan.edu

\section{Integrated pest management for resource- limited farmers: challenges for achieving ecological, social and economic sustainability}

\author{
D. G. Bottrell ${ }^{1, \star}$ and K. G. Schoenly ${ }^{2}$
}

${ }^{1}$ Department of Entomology, University of Maryland, College Park, MD 20742, USA and ${ }^{2}$ Department of Biological Sciences, California State University, Stanislaus, 1 University Circle, Turlock, CA 95382, USA

\begin{abstract}
Hailed as the single most important paper published on crop protection in the 20th century, Stern et al. in 1959 formed the conceptual basis for modern integrated pest management (IPM) worldwide. The ecological foundation for IPM envisioned by its authors is as valid today as in 1959. However, adoption by developing country farmers has been low and its advances short-lived. The present paper examines the concept of integration in IPM and criteria for determining whether its control tactics have been integrated harmoniously. The effects of local and regional landscape patterns on pests and on the design of IPM are reviewed, arguing that the agroecosystem must be understood and managed as a living system with the goal of enhancing and conserving agrobiodiversity and keeping ecosystem services intact. Key to IPM adoption is convincing farmers to integrate non-chemical alternatives (e.g. biological control, plant diversification) as primary management components and to apply pesticides judiciously and only after non-chemical components fail to manage pests effectively. Research, extension and policy changes are identified to increase the efficiency, adoption and sustainability of IPM on resource-limited farms. The over-arching challenge is devising communication and support systems that allow resource-limited farmers to try, adopt and sustain IPM that enhances yields and profits in light of the many uncertainties and challenges. Use of information technology, media development, crowdsourcing and rural sociology is advocated to connect farmers to the technical sources required to enhance yields and profits and reduce risks to them, the farming community and the environment.
\end{abstract}

\section{Introduction}

In the late 1950s, chemical companies ramped up production of insecticides, which proliferated in many agricultural crops (Osteen and Szmedra, 1989). Concurrently, Stern et al. (1959) introduced a strategy called 'integrated control' to harmonize chemical and naturally occurring biological control in a unified, ecologically sound insect management system. Stern et al. (1959) influenced crop protection worldwide and moulded the conceptual basis for modern integrated pest management (IPM). In 1981, when its second author Ray F. Smith was elected to the US National Academy of Sciences for advancing IPM worldwide, the Stern et al. (1959) article was pronounced as 'the single most important paper published on crop protection in this century' (Warnert, 2009). In 1972, President Nixon directed federal government agencies in the USA to advance the concept and application of IPM in agriculture, urban areas, forestry and other relevant sectors (Nixon, 1972). In 1979, President Carter established an inter-agency IPM coordinating committee to ensure development and implementation of IPM practices by all federal agencies in the USA (Bottrell, 1979). Previously, the Food and Agriculture Organizations of the United Nations launched an FAO-UNEP cooperative global programme for the development and application of integrated pest control in developing countries (FAO, 1975; Brader, 1979).

The seminal integrated control strategy of Stern et al. (1959) systematically combined insecticides and biological control to manage the spotted alfalfa aphid [Therioaphis maculata (Buckton)] of alfalfa [Medicago sativa (L.)]. Eventually, other chemical, biological and physical tactics were incorporated to manage insect, plant pathogenic, weed, snail, vertebrate and other pests of dozens of agricultural crops (Kogan, 1998; Way and van Emden, 2000; Maredia et al., 2003; Kogan and Jepson, 2007; Koul et al., 2008; Peshin and Dhawan, 2009a, 2009b; Abrol and Shankar, 2012; Abrol, 2014; Coll and Wajnberg, 2017a). In addition to entomologists, plant pathologists, weed scientists, nematologists and other pest specialists, economists and sociologists have contributed to the concept, design, implementation and evaluation of IPM programmes.

In the first major review of integrated pest control schemes in developing countries, Brader (1979) reported that the integrated strategy had reduced pesticide use and provided more 
durable crop protection in agricultural crops of Africa, Asia, Latin America and the South Pacific. More than three decades later, Pretty and Bharucha (2015) assessed outcomes on productivity and reliance on pesticides using published data from 85 IPM projects in 24 countries in Asia and Africa. Except for Japan, all were developing countries. The IPM projects had been implemented on several food and cash crops since 1990; the time elapsed from project start to measurement of reported impact varied from 1 to 5 years. Pretty and Bharucha (2015) found a highly variable but mean yield increase across projects and crops of $40.9 \%$ (SD 72.3) and a highly variable but mean decline in pesticide use of $30.7 \%$ (SD 34.9), compared with the baseline. They estimated that 10-20 million farmers on 10-15 million hectares had adopted IPM in these projects.

Despite IPMs demonstrated potential in developing countries, its adoption rate has been low and its advances short-lived. Brader's (1979) review noted the lack of an effective independent extension service, de-linked from pesticide merchandizing, as a major hindrance. More than 35 years later, Parsa et al. (2014) used structured concept mapping (Trochim, 1989) to survey IPM specialists for open-ended opinions on obstacles that prevent IPM's adoption in developing countries. Respondents from 96 countries identified 51 unique obstacles. Subsequently, 163 participants of an international workshop rated the obstacles according to importance and remediation difficulty. Developing country participants rated 'IPM requires collective action within a farming community' as the top obstacle whereas high-income country participants prioritized 'shortage of well-qualified experts and extensionists' (Parsa et al., 2014). Developing country participants also rated 'shortage of practices and products as effective as chemical pesticides' and 'IPM research poorly oriented to needs of farmers' as two other priorities that differed significantly from high-income country participants. Notwithstanding its low adoption rate in developing countries, IPM potentially offers the best route to economically efficient crop protection that increases and sustains farm productivity while minimizing threats to humans and the environment.

\section{Aims of the paper}

The current review highlights obstacles hindering IPM's adoption and sustainability on resource-limited farms in developing countries and presents pathways for overcoming them. Firstly, the conceptual basis of IPM and the criteria for determining if control tactics have been integrated harmoniously in IPM programmes are examined. The effects of local and regional landscape patterns on pests and why it is important to consider these effects in designing IPM are then reviewed, as well as the ecological features of the agroecosystem and procedures for making IPM an integral and durable component of this living system, and the huge challenge of connecting the vast population of resource-limited farmers to reliable information and technical sources required to sustain IPM.

\section{Integrating integrated pest management tactics: theory v. application}

\section{Integrated pest management's conceptual foundation}

Stern et al. (1959) clearly articulated a concept for integrating chemical control and biological control in a cohesive, ecologically based insect management scheme using decision-making guidelines. These and many other entomologists recognized biological control as a key tactic of the ecologically based strategy. van den Bosch et al. (1982), for example, asserted that 'biological control is in its essence an ecological phenomenon and in its practice is an example of "applied" ecology'. However, as additional control tactics were incorporated into pest management schemes and specialists other than entomologists contributed, IPM often veered from the original paradigm (Ehler, 2006; Coll and Wanjberg, 2017b). It even became a convenient term to rationalize the unilateral use of pesticides without considering alternative methods (Barfield and Swisher, 1994; Kogan, 1998; Power, 1999; Ehler and Bottrell, 2000; Ehler, 2006). Although IPM has no uniformly accepted definition (Coll and Wajnberg, 2017b), Kogan (1998) defined IPM thus: 'IPM is a decision support system for the selection and use of pest control tactics, singly or harmoniously coordinated into a management strategy, based on cost/benefit analyses that take into account the interests of and impacts on producers, society and the environment.' (Kogan, 1998). This definition would foster broad unanimity among those who view ecologically based IPM as a necessary, integral component of profitable, environmentally safe sustainable agriculture. The current paper upholds Kogan's (1998) definition and also his conceptual framework for an IPM strategy. Asian rice (Oryza sativa L.) and insect biases are acknowledged in the examples and discussions in the present paper, although the principles of IPM apply to the management of a broad range of potentially harmful organisms insects, plant pathogens, plant nematodes, snails, weeds, rodents, etc. - that interfere with profitable production of all crops.

Stern et al. (1959) systematically combined only insecticides and biological control to manage a single pest species. Integrated pest management specialists later devised management strategies for multiple species of pests and embedded additional pest avoidance and control tactics such as pest-resistant crops, crop rotation and water and fertilizer management. The IPM concept eventually evolved with a focus on the entire agroecosystem and consideration of social, economic, marketing and political factors affecting IPM adoption. Prokopy (1993) likened this evolution to climbing a stepladder: the first step was limited to the judicious and educated use of insecticides for managing a single class of pests; later steps evolved in hierarchical order with ascending levels of complexity and expanding spatial scales.

\section{Different levels of integration}

Using Kogan's $(1988,1998)$ hierarchical system (Table 1), integration of pest control methods and decision making in IPM occurs at three basic levels: I - one pest species or a group of related pest species; II - multiple pest categories (e.g. insects, pathogens and weeds); and III - within the context of the total cropping system (ecosystem level integration) (Kogan, 1988, 1998). Prokopy and Croft (1994) added a fourth level: IV - integration of psychological, social, political and legal constraints to IPM (Table 1). Most IPM schemes have targeted a single pest species or a group of taxonomically related species (level I integration) or multiple pest species (level II integration) and not the ecosystem (level III integration) or local farming community (level IV integration). Without successful integration at all levels, IPM will not deliver fully on its promises.

\section{Harmonization of tactics}

A fundamental paradigm of IPM is that the use of multiple tactics provides crop protection that is less risky, more technically 
Table 1. Levels of integration in IPM after Kogan (1988, 1998) and Prokopy and Croft (1994)

\begin{tabular}{|c|c|c|}
\hline Level of integration & Focus of the IPM effort & Examples of what must be integrated \\
\hline $\begin{array}{l}\text { I Individual pest } \\
\text { species }\end{array}$ & $\begin{array}{l}\text { One pest species or a group of taxonomically } \\
\text { related pest species (vertical) }\end{array}$ & $\begin{array}{l}\text { Pesticide + biological control to suppress an insect pest or two related insect } \\
\text { pests }\end{array}$ \\
\hline \multirow[t]{3}{*}{$\begin{array}{l}\text { Il Communities of } \\
\text { pest species }\end{array}$} & $\begin{array}{l}\text { Multiple pest species of unrelated taxa } \\
\text { (horizontal) }\end{array}$ & $\begin{array}{l}\text { Plant resistance + biological control + physical control to suppress animal pests } \\
\text { (insects, nematodes, molluscs, vertebrates) }\end{array}$ \\
\hline & & Plant resistance to suppress plant pathogens (viruses, bacteria, fungi) \\
\hline & & Herbicide + cultivation + physical control to suppress weeds \\
\hline III Ecosystem & $\begin{array}{l}\text { All crops, wild vegetation and other } \\
\text { components of the agroecosystem }\end{array}$ & $\begin{array}{l}\text { All tactics directed at all pests of all crops in the agroecosystem; the tactics } \\
\text { may include manipulations of native or other non-crop vegetation }\end{array}$ \\
\hline $\begin{array}{l}\text { IV Local farming } \\
\text { community }\end{array}$ & $\begin{array}{l}\text { Rural community for which IPM is projected } \\
\text { to help }\end{array}$ & Social, economic, marketing and political factors affecting IPM adoption \\
\hline
\end{tabular}

efficient and more cost-effective than the use of a single tactic. Stern et al. (1959) advocated applying insecticides sparingly and only as necessary to prevent the spotted alfalfa aphid's population from surpassing an established economic injury level. Frugal use of insecticides saved the farmers money and caused less harm to natural enemies operating against the spotted alfalfa aphid and other alfalfa insect pests. Integrated crop protection programmes that have combined pesticides and biological control, as advocated by Stern et al. (1959), have been used successfully against many agricultural insects and also spider mites (Croft, 1990). Harmonizing pesticides and biological control or other tactics to control a pest theoretically reduces the risk of crop loss if one of the tactics fails. If unfavourable weather reduced the effectiveness of natural enemies or chemical control, for example, the farmer should still benefit from a control tactic that is less weatherdependent such as plant resistance or crop rotation. Furthermore, by combining different tactics the probability that a pest will adapt to any one tactic should be less; this is based on evolutionary models which predict that the less a given control method challenges a pest, the longer it will take for the pest to adapt to the control method (Gould, 1991). Liu et al. (2014) provided empirical evidence that natural enemies slowed the development of insect pest resistance to 'Bt crops' engineered with genes of the soil bacterium Bacillus thuringiensis Berliner. In greenhouse studies, Liu et al. (2014) showed that the insect predator Coleomegilla maculata (DeGeer), combined with non- $B t$ and unsprayed refuge plants, delayed resistance in the diamondback moth [Plutella xylostella (Linnaeus)] population to Bt broccoli (Brassica olercaea L.) plants, when compared with treatments without the predator.

\section{Level I integration challenges}

Mixing different control tactics randomly will not necessarily produce better results than a single tactic; in some cases, the combination may trigger antagonistic effects and potentially reduce crop yields and farmer profits (Kogan, 1988, 1998; Thomas, 1999; Ehler and Bottrell, 2000; Ehler, 2006). For example, while host-plant resistance and biological control are usually compatible, the morphological, physiological or chemical traits of insect-resistant cultivars may discourage or even cancel out the potentially beneficial effects of a natural enemy (Gould et al., 1991; Hare, 1992; Johnson and Gould, 1992; Bottrell, et al., 1998; Thomas, 1999; Tandon, 2001; Kennedy and Gould, 2007). The outcome of the interaction will depend on the specific relationship between the pests and their natural enemies and how the resistant plants affect both. Hare's (1992) models show that, without natural enemies, the equilibrium density of a pest declines linearly with increasing levels of plant resistance. But when the relationship is additive, host-plant resistance and biological control act independently on a pest's equilibrium density. In other words, the biological interaction between the two tactics does not occur and mortality due to natural enemies is uniform across plant genotypes with different levels of resistance. By contrast, in antagonistic and synergistic relationships, resistance affects both pests and natural enemies. In extreme cases of antagonism (i.e. disruptive relationships), plant resistance could affect natural enemies more than pests and therefore reduce the effectiveness of biological control (Tandon, 2001).

Table 2 provides examples of possible outcomes when two pest control tactics, $\mathrm{A}$ and $\mathrm{B}$, are combined. If tactic $\mathrm{A}$ alone achieved $40 \%$ pest control and tactic B alone achieved 50\% control, then deployed together $90 \%$ control would indicate additive effects, $>90 \%$ control would indicate synergistic (multiplicative) effects and $<90 \%$ control would indicate antagonistic effects. Either additive or synergistic effects would suggest that the two IPM tactics are compatible. Antagonism, on the other hand, would suggest that the tactics may not be compatible. Some antagonism may be acceptable but not if one of the tactics significantly disrupts the effectiveness of another, resulting in hardship to the farmer. A commonly reported unacceptable level I antagonistic interaction is when an insecticide, which is effective against an insect pest, destroys natural enemies that contribute significantly to the pest's regulation (Hardin et al., 1995). Fagan et al. (1998) found that when rice insect pests were exposed simultaneously to the wolf spider [Lycosa pseudoannulata (Bösenberg and Strand)] and the insecticide monocrotophos, the treatments cancelled each other out. Szczepaniec et al. (2013) discovered that neonicotinoid insecticides have the potential to suppress plant defence genes, alter plant defence phytohormones and decrease plant resistance to unsusceptible herbivores on distantly related crop plants.

\section{Level II integration challenges}

Combining tactics horizontally across different pest groups can produce potentially complex interactions (Ehler and Bottrell, 2000; Ehler, 2006). Examples of negative interactions would be when an insecticide kills natural enemies that protect crops from insect pests or destroys insects that suppress crop weeds; when a fungicide destroys microbial antagonists of plant pathogens or kills predatory mites that control plant feeding mites; 
Table 2. Examples of possible outcomes when tactics $A$ and $B$ are used alone and in combination to control a pest

\begin{tabular}{lcccc} 
& \multirow{2}{*}{$\begin{array}{c}\text { Percentage } \\
\text { control when } \\
\text { used alone }\end{array}$} & & Percentage control when combined \\
\cline { 3 - 5 } & 40 & Additive & Synergistic & Antagonistic \\
\hline A & 50 & & & \\
\hline B & & 90 & $>90$ & $<90$ \\
\hline A and B & & No & Yes & Yes \\
\hline $\begin{array}{l}\text { Biological } \\
\text { interaction? }\end{array}$ & & & & \\
\hline
\end{tabular}

and, as recently discovered, when a pesticide suppresses plant resistance (Szczepaniec et al., 2013). Entomologists have documented broad-spectrum ecological effects of pesticides on multiple pest and natural-enemy populations. van den Bosch et al. (1982) coined this phenomenon the 'trifaceted insecticide treadmill' in reference to a target pest's resurgence, a secondary pest's outbreak and resistance in the target pest, or even one or more non-target pests. A non-chemical tactic could also trigger negative interactions. For example, switching to an improved crop cultivar with genetic resistance to an insect pest may control the insect effectively but aggravate a plant pathogen or vice versa (Bonman et al., 1992). Or, as previously discussed, a crop cultivar that is resistant to an insect pest could deter natural enemies that regulate its abundance.

\section{Levels III and IV integration challenges}

Level III integration involves integrating all crops, wild vegetation and other components of the agroecosystem. Sections 'Effects of local and regional landscape' and 'The agroecosystem as a living system' of the present paper are devoted entirely to level III integration. However, as emphasized in the section 'Sustaining the Integrated Pest Management Effort', even if all pest control tactics are integrated in a compatible manner, the IPM scheme will not endure unless it is tailored for the local socioeconomic environment and can resist conflicting market forces (level IV integration).

\section{Integrated pest management and sustainable agriculture}

Integrated pest management is a complementary and necessary feature of sustainable agriculture, which aims to assure equitable, secure, sufficient and stable flows of both food and ecosystem services (Tilman et al., 2002). Agriculture will achieve sustainability only if the agroecosystem maintains stable productivity while resisting major disturbances including pest ravages (Conway, 1993). Ecologists generally equate ecological stability with ecological resilience, defined as the degree to which a population or community returns to its previous configuration once the perturbation is removed (Pimm, 1991). Populations and communities with high resilience are expected to show relatively low levels of fluctuation and recover relatively quickly from disruptions (May, 1976). Although ecological communities consistently reveal low resistance to species introduction (Herbold and Moyle, 1986; Savidge, 1987; Nichols et al., 1990; Knapp et al., 2001), some exhibit relatively high levels of resilience following the initial disruption (Knapp et al., 2005). In agroecosystems, IPM theoretically reduces the frequency and intensity of pest turbulence by eliminating disruptive pest control methods and enhancing ecosystem services that contribute to ecological resilience. For example, routine use of insecticides reduces the inherent resilience in high-yielding rice in tropical Asia by triggering ecological disruptions that cause major insect pest outbreaks (Kenmore et al., 1984; Heinrichs and Mochida, 1984; Heong and Hardy, 2009; Bottrell and Schoenly, 2012). Minimizing insecticide use and relying on plant resistance, natural enemies and habitat management as primary management components can contribute to the restoration of ecological resilience in highyielding rice (Gallagher et al., 1994, 2009; Matteson, 2000).

Ludwig et al. (1993) argued that achieving sustainability through scientific and technological progress is a daunting task, due primarily to wide variability and unpredictability of different components of the exploited ecosystem. Resource managers have traditionally used deterministic (non-random) age- or stagestructured population models to estimate harvest sizes (Clark, 1985). However, as they develop and age, all biological populations experience random (stochastic) variation from abiotic (environmental) and biotic (ecological, anthropogenic) sources (Gatto, 1995). Incorporating stochastic variation into structured population models (i.e. stochastic demographic models) alters estimates of population growth rates, persistence and resilience that can ultimately affect community composition, species interactions, distributions and harvesting (Boyce et al., 2006). An example of ecological complexity and unpredictability that upholds this 'precautionary principle' in agroecosystems is intraguild predation (IGP), which occurs when two or more predators, parasitoids or pathogens compete for the same prey or hosts. Intraguild predation is widespread in natural and agricultural systems (Polis et al., 1989; Rosenheim et al., 1995; Arim and Marquet, 2004; Denno and Finke, 2006). However, many factors affect IGP's strength during the season and create difficulty in predicting if the multiple natural enemies are interacting harmoniously or antagonistically against crop pests. Integrated pest management will not contribute to long-term sustainability if it fails to find alternative tactics that reduce such uncertainty.

Ideas for increasing sustainability and reducing uncertainty have emerged from long-term agricultural trials and by infusing core evolutionary principles (Denison, 2012). Because causal relationships are difficult to detect on working farms, determining which farmer interventions bring consistency in crop yields depends on scientific data from decades-long experiments on research farms. For example, at the Rothamsted Agricultural Research Station in the UK (the longest continuously active research farm), long-term data show that grain yields of wheat (Triticum aestivum L.) and barley (Hordeum vulgare L.) were sustained (and even increased) for nearly the entire 160 years in monoculture under annual applications of either organic or inorganic fertilizers (Jenkinson, 1991). The 160-year archive included enough DNA from two fungal pests to reveal past crop-pathogen epidemics linked to changes in air pollution (Bearchell et al., 2005). By viewing sustainability through an evolutionary lens, Denison (2012) argued that solutions for improving crop yields may come from a better understanding of the trade-offs and how agroecosystems influence pest evolution. During the Green Revolution, when crop breeders 'reversed' past natural selection by developing shorter-stature, higher-yielding wheat and rice varieties, trade-offs came in the form of lower competitiveness from taller plants. Similar reversals, Denison (2012) argued, could involve breeding plants with less aggressive roots, leaving them 
with more resources to invest in grain. Many questions that agroecologists must address will require understanding adaptations of wild species in their natural environments (Denison, 2012). Taking the long view invites IPM practitioners to build on lessons learned from long-term experiments and to apply evolutionary principles and ecological concepts leading towards improved agricultural productivity and sustainability.

Ludwig et al. (1993) argued that achieving sustainability will also require increased collaboration among environmental and social scientists. Such efforts can help guide decision makers and the public with options, costs and benefits (Ehrlich and Daily, 1993). Although collaboration will not guarantee the best possible outcome, it should lessen the level of farmer uncertainty, particularly if the precautionary principle (cited above) is exercised to guide actions (Costanza, 1993).

\section{Effects of local and regional landscape}

The landscape in which a crop is embedded plays an important role in defining and developing the IPM system (Goodell, 2009). Although three-quarters of the estimated 280 million farms in low-income and lower middle-income countries are $<2$ ha in size (Lowder et al., 2016), they are often highly diverse with a dominant food crop such as rice, maize (Zea mays L.), or potato (Solanum tuberosum L.), garden vegetables and fruit trees and often wandering or fenced livestock (Vandermeer, 1989). Larger farms may include a cash crop such as cotton (Gossypium sp.). The neighbouring crops, weeds and wild habitat on or surrounding the farm potentially influence the dynamics of a crop's pests and natural enemies. Indeed, local diversification, from within field (polyculture) and or around field (e.g. hedgerow) sources, may enhance natural pest control and compensate for low-complexity at the larger landscape level (Chaplin-Kramer and Kremen, 2012; Morandin and Kremen, 2013). An insect pest with a wide plant host range may feed or reproduce on several or even all of the area's crops and sometimes crop weeds and vegetation in nearby wild habitat and the pest may be 'tracked' by natural enemies as it switches host plants (Settle et al., 1996; Barbosa, 1998; Letourneau, 1998; Landis et al., 2000; Kennedy and Gould, 2007). Some crops serve as aggregation and reproduction sites for natural enemies and will sustain the enemies until food and habitat requisites are exhausted (Kennedy and Gould, 2007). The enemies will then disperse to other crops or wild habitats. Weeds within or near a crop may host pathogens and invertebrate pests. Weeds are particularly important in maintaining or increasing populations of nonmobile pest organisms such as Verticillium and Fusarium pathogens, and root-knot and cyst nematodes (Norris, 2007). They also may serve as refuges for natural enemies (Norris and Kogan, 2000). In tropical irrigated Asian rice, for example, egg parasitoids Anagrus spp. and Oligosita spp. of pest leafhoppers and planthoppers, respectively, live in nearby Echinochloa- and Leptochloa-rich habitats, respectively (Yu et al., 1996). Other weedy grasses such as Paspalum spp. bordering tropical rice support sizeable populations of gryllid crickets [e.g. Anaxipha longipennis (Serville) and Metioche vittaticollis (Stål])] that are efficient predators of rice leaffolder [Cnaphalocrocis medinalis (Guenée) and Marasmia spp.] eggs (de Kraker, 1996). Tropical Asian rice also harbours a rich mix of aquatic predators (Settle et al., 1996; Schoenly et al., 1998; Wilson et al., 2008) that attack the crop's pests (Nakasuji and Dyck, 1984; Settle et al., 1996; Schoenly et al., 1998). Therefore, an IPM programme developed for a crop without considering the effects of the neighbouring crops, wild vegetation and aquatic systems in or nearby the crop could produce disappointing results.

\section{Relationship in plant diversity and pest abundance}

Pimentel's (1961) seminal paper, which showed that plant mixtures prevented outbreaks of insect pests in collards (Brassica oleracea L.), stimulated interest in determining the relationship in the vegetational diversity of agroecosystems and pest abundance. Risch et al. (1983) evaluated 150 published studies that measured the effect of crop diversification on insect pests in 140 annual crops (harvested and destroyed in 1 year or less of planting) and 58 perennial crops such as fruit trees that grew in the same place for years. Of the 198 species of pests in the studies, $53 \%$ were less abundant in the more diverse cropping systems, $18 \%$ were more abundant in the diverse systems, $9 \%$ showed no difference and 20\% showed a variable response. In Andow's (1991) evaluation of 209 published studies, $52 \%$ of the 287 herbivore species had lower densities on plants in polycultures than in monocultures; only $15 \%$ (44 species) had higher densities on plants in polycultures than monocultures. Letourneau et al. (2011) used meta-analysis to evaluate 552 experiments in 45 journal articles to test if plant diversification schemes reduced crop-feeding pests and/or increased their natural enemies. Overall, pest suppression, natural enemy enhancement and crop damage suppression effects were significantly stronger in the more diverse cropping systems. Although analysis by Poveda et al. (2008) of 62 published studies of crop diversification practices showed that diversification enhanced natural enemies, reduced pest pressure and increased yield respectively in only 52, 53 and $32 \%$ of the cases, the authors concluded that the appropriate mix of plant diversity could reduce pests and maintain yield effectively.

\section{Manipulating plant diversity to manage pests}

Before modern pesticides, crop protection specialists often sought plant diversification strategies that would mitigate pest damage. The emphasis waned after modern post-World War II pesticides proliferated, but contemporary researchers have renewed efforts to combine biological pest control with habitat manipulation and landscape-level management (Barbosa, 1998; Pickett and Bugg, 1998; Philips et al., 2014). Recent examples of successful plant diversification schemes aimed at reducing pests on resourcelimited farms are the 'push-pull' strategy for African cereal crops and the planting of nectar-rich companion plants in monocultures of rice in Asia. The push-pull strategy in Africa (Khan et al., 2016) uses native companion plants such as Napier grass (Pennisetum purpureum Schumach) - the 'pull' - to attract cereal stemborers (of the families Crambidae, Pyralidae and Noctuidae), while simultaneously driving them away from the cereal crop using a repellent intercrop like Desmodium spp. - the 'push'. Chemicals released by the Desmodium spp. roots control the parasitic African witchweed [Striga hermonthica (Del.)] by inducing suicidal germination of the witchweed's seeds in the soil and thereby preventing the weed from attaching to the cereal plants' roots. Both Napier grass and Desmodium spp. provide animal fodder, boosting milk production when fed to dairy animals, and Desmodium spp. enhance soil fertility by fixing nitrogen, while acting as a cover crop to retain soil moisture. The pushpull strategy complements traditional mixed cropping systems of Africa and thousands of resource-limited farmers have adopted 
it (Khan and Pickett, 2004; Cook et al., 2007; Khan et al., 2008, 2016; ICIPE, 2013).

In Thailand, China and Vietnam, multi-site 4-year studies replicated on farmers' fields revealed impressive benefits when farmers planted locally appropriate nectar-producing dicotyledonous plants around their rice fields to increase biological control of insect pests (Gurr et al., 2016). The flowering companion plants (species varied among locations) provided nectar, pollen and shelter to important species of natural enemies. Farmers planted the nectar-rich flowering plants on the rice bunds (narrow elevated bands of soil arranged around rice fields to retain water) and field margins to conserve natural enemies. This inexpensive intervention significantly reduced populations of two major insect pests, brown planthopper (Nilaparvata lugens Stål) and white backed planthopper [Sogatella furcifera (Horváth)], reduced insecticide applications by $70 \%$, increased grain yields by $5 \%$ and enlarged farmer profits by $7.5 \%$. Encouraged by the results, the Vietnamese government launched media campaigns to encourage adoption of the practice (Heong et al., 2014).

Whether the recently adopted push-pull strategy for African cereal crops and the planting of nectar-rich companion plants in monocultures of rice in Asia will endure remains to be seen. Nevertheless, both are good examples of low-cost IPM programmes that have evolved from a local landscape view and integrated into the resource-limited farming operations.

\section{From ecological theory to practice}

Ecologists have offered various hypotheses to explain why pests and natural enemies often respond differently to plant mixtures than to pure stands (for a summary, see Poveda et al., 2008). For example, Root's (1973) 'resource concentration hypothesis' postulates that lower herbivore abundance prevails in diverse vegetation because the herbivore's host plants are less concentrated and therefore harder to find. Also, some plant species in the diverse system may serve as repellents, as illustrated by Desmodium spp. in the African push-pull system (Cook et al., 2007). Root's (1973) 'enemy hypothesis' advocates that natural enemies occupying the middle trophic levels determine the abundance of herbivores in a habitat. The diverse system offers more alternate prey and plant food sources such as pollen and nectar to generalist natural enemies, which in turn reduce pest abundance. The 'trap crop hypothesis' suggests that alternative host plants (e.g. Napier grass in the African push-pull system, Cook et al., 2007) lure pests away from the primary crop plants (Vandermeer, 1989). The 'barrier crop hypothesis' advocates that taller non-host plants in a mixed cropping system obstruct movement of insect pests, thereby reducing their chance of colonizing the primary crop plants (Perrin and Phillips, 1978). The 'associational resistance hypothesis' states that non-host plants release odour-masking substances that make the crop 'invisible' to insect pests (Tahvanainen and Root, 1972).

Ecological theory helps to design field experiments that measure the effects of different non-host or alternative host plants on pests and natural enemies and their suitability in plant diversification schemes. However, high variability in the responses of pests and natural enemies to plant diversification impedes efforts to devise general rules about expected outcomes (Andow, 1983, 1991; Kareiva, 1983; Risch et al., 1983; Coll and Bottrell, 1994; Landis et al., 2000; Poveda et al., 2008; Letourneau et al., 2011). The diversification schemes should be evaluated on a case-by-case basis. The crop species, non-crop plant species, pests to be managed, natural enemies, climate, farmer resources and other factors will determine what specific mix of vegetation is best suited for a specific farming system (Poveda et al., 2008). The need to develop practical schemes that harmoniously blend into individual farming operations and yield beneficial returns is implicit. Along with this line, Letourneau et al. (2011) found that while plant diversification schemes generally reduced pests and pest damage, and enhanced natural enemies, they slightly but significantly reduced crop production because the intercrops or noncrop plants effective in reducing pest abundance used space that would have otherwise been filled by the main crop. In some cases, the savings in pesticides may outweigh the loss in yield but in other cases, they may not. Individual farmers may not be able to implement some plant diversification schemes without the cooperation of farmer associations or regional organizations, for example, that control regional irrigation systems and water delivery rates.

\section{The monoculture alternative}

Diversifying the cropping system has many advantages and may be necessary to achieve the most effective crop protection in some situations. However, this does not mean that crop monocultures are necessarily inherently vulnerable to pests. For example, monocultures of rice in tropical Asia with reasonable levels of insect resistance rarely experience damaging insect outbreaks unless treated with natural enemy-disrupting insecticides (Heong and Hardy, 2009; Bottrell and Schoenly, 2012). The brown planthopper, the potentially most damaging insect pest of tropical Asian rice, occasionally reaches moderately high densities even on resistant cultivars during periods of high predation (Schoenly et al., 2010). However, unless disturbed by insecticides, natural enemies flourish in the rice monocultures and prevent the brown planthopper and other potentially harmful insect pests from attaining damaging levels (Kenmore et al., 1984; Cohen et al., 1994; Settle et al., 1996). On the other hand, Gurr et al. (2016) showed that diversifying rice monocultures with nectarrich plants may yield significant pest management benefits in some areas of tropical Asia.

Mixing different genetic forms (multiline cultivars and cultivar mixtures) of the same crop species might be a suitable alternative to plant species diversification, especially for managing certain diseases of small grains (Browning et al., 1977; Mundt, 2002). In China, rice blast disease caused by the fungus Pyricularia oryzae Cavara was $94 \%$ less severe in cultivar mixtures of rice than in single cultivar stands (Zhu et al., 2000). Disease-susceptible rice cultivars planted in mixtures with resistant cultivars had $89 \%$ greater yield than when planted alone. The mixtures achieved an overall higher yield of $18 \%$ with mixtures, but this may have been an artefact due to the sub-optimal density of the monoculture control (Denison et al., 2003). Mixing rice cultivars may be an effective alternative to fungicides and may also reduce the dependence on high levels of plant disease resistance (Zhu et al., 2000). However, cultivar mixtures are more useful under some conditions than others and experimental methodology (especially problems of scale) may be crucial in evaluating their potential (Mundt, 2002).

\section{The agroecosystem as a living system}

Although modern crops may contain fewer species than their wild relatives (Chen et al., 2013, 2015), they still support highly 
complex communities of organisms and food webs. Agrobiodiversity plays essential roles in soil nutrient cycling, erosion control, mineral retention, regulation of pests, pollination, water quality and other ecological services (Power, 1999; Tilman et al., 2002; Gurr et al., 2003; Brussaard et al., 2007; Smukler et al., 2010; Tomich et al., 2011; Gliessman, 2015). To capture the ecosystem services required for productive sustainable agriculture, agroecosystems must be managed as living systems (Matson et al., 1997).

\section{Insights into the agrofoodweb}

Heckman (1979) documented 590 species of plants (besides rice) and animals in a single irrigated rice field in Thailand and his inventory excluded insects and spiders, which are the most common invertebrate species in rice (Cohen et al., 1994). Cohen et al. (1994), Settle et al. (1996), O’Malley (1999) and Bambaradeniya et al. (2004) recorded more than 640, 760, 500 and 490 taxa of macro-invertebrates in Philippine, Indonesian, American and Sri Lankan irrigated rice fields, respectively. Pathummal Beevi et al. (2000) and Sebastian et al. (2005) recorded 84 and 92 species, respectively, of hymenopteran parasitoids and spiders, respectively, in Indian irrigated rice. In a study aimed at estimating total macro-invertebrate richness in an irrigated Philippine rice field, Schoenly and Barrion (2016) recorded 340 rice plant canopy taxa and 60 aquatic taxa over two cropping seasons, representing inventory completeness of approximately $82 \%$ for the canopy and $98 \%$ for the floodwater. Comparable inventories of crop soil organisms have been limited (Hughes et al., 2001) although it is assumed that a handful of rich organic soil may contain millions of organisms representing hundreds of different species of bacteria, fungi, protozoa, algae and micro-invertebrates (Behan-Pelletier and Newton, 1999).

Functional traits of individual species, rather than functional groups or species richness per se, is the dimension of biodiversity most directly related to ecosystem functioning (Tilman and Downing, 1994; Naeem and Wright, 2003; Cadotte et al., 2011). The species may influence ecosystems directly (e.g. pollination, predation, parasitism, herbivory, competition) or indirectly by responding to local environmental changes such as microclimate or human disturbances (Chapin et al., 2000). The functional traits govern the impacts of species on the environment and also species fitness (Lavorel and Garnier, 2002; Wood et al., 2015). Erosion of the functional traits through species losses may negatively impact community and ecosystem processes (Chalcraft and Resetarits, 2003).

Studies of food webs are highly labour intensive and require specialized taxonomic services and trophic specialists but may be essential to clarify the functional traits of individual species (Neuenschwander et al., 1987; Cohen et al., 1994; Rosenheim et al., 1995). Understanding interactions in the food web offer insights into the food sources of individual species and to whom they, in turn, serve as food and can identify pathways to phenomena such as top-down, bottom-up and indirect effects (Morin, 2011). Traditional food webs have been depicted as qualitative, who-eats-whom networks that rarely identify the strong interactors among community members (Bowman et al., 2017). Beginning with Paine (1966), however, manipulative field experiments have determined that energy flow may be governed by one or more species coined by Paine (1969) as 'keystone species'. These domineering species maintain community diversity by exerting strong direct and indirect effects on inferior species that could otherwise dominate the community (Bowman et al.,
2017). Keystone species have mixed impacts on different functional groups in cropping systems. In a cropping system in Mexico planted to maize and squash (Cucurbita moschata Duchesne), the dominant tropical fire ant [Solenopsis geminata (Fabricius)] significantly reduced populations of insect herbivores and, to a lesser extent, arthropod predators (Risch and Carroll, 1982). The aggressive fire ant had multiple impacts on the other predators, consuming some and competitively excluding others by eating their available prey. Kaplan and Eubanks (2002) found that the imported red fire ant [Solenopsis invicta (Buren)], an invasive species in the USA, increased survival and density of the cotton aphid (Aphis gossypii Glover) by releasing the aphid pest from predation by lady beetle larvae.

Predicting how the environment and management practices affect important ecosystem services in the agroecosystem requires knowledge of which organisms produce specific services such as pollination or biological control (Zhang et al., 2007; Power, 2010; Kremen and Miles, 2012; Wood et al., 2015). Traditional food webs only depict linkages between trophic levels (i.e. vertical relationships), such as predator-prey, plant-herbivore and parasitoid-host interactions (Bowman et al., 2017). However, any complex ecological community includes many non-trophic (horizontal) interactions (Morin, 2011), such as competition, host-switching and mutualism. The more recently introduced 'interaction web' depicts the broader set of trophic and nontrophic pathways that occur among members of an ecological community (Bowman et al., 2017). The interaction web of an agroecosystem in Fig. 1 (modified from Norris et al., 2003) shows the traditional set of interconnected food chains (i.e. detritus, crop, weed) plus non-trophic and other interactions that might be overlooked or sloughed off as unimportant (e.g. services of detritivores in biological control, host switching by insect herbivores, IGP among natural enemies of pest species, allelopathy between crop and weed species, plant pollination and other mutualistic networks). In each food chain, every organism occupies a trophic level defined by how many energy transfers separate it from the basic input of the chain. Crop plants and weeds make their own organic molecules and are the agroecosystem's foundation producers ('basal species'). The assemblage of consumers (herbivores, predators, parasitoids, hyperparasitoids, vertebrates) supported by the crop plants and weeds must eat other organisms to obtain their organic molecules. Detritus, which is dead particulate organic matter (crop plant and weed debris, bodies or fragments of dead organisms, animal faeces, etc.), supports decomposers (microbes), scavengers (invertebrates, including alternate prey) and sometimes vertebrates.

Using standard food web terminology (Cohen, 1978; Briand, 1983), the left-hand column of Fig. 1 shows the different links in the food chain, starting with basal species (crop or weed and detritus) at the bottom and ascending upwards with top predators at the summit. Insect and other herbivore pests and pathogens are 'middle species'. Also included in the middle species categories are insects and other organisms that serve as beneficial predators and parasitoids, and prey and hosts for the predators and parasitoids. Certain insectivorous frogs, birds and bats, often ignored in IPM programmes, are major top predators of insect pests in cotton, cacao (Theobroma cacao L.) and rice ecosystems (Cleveland et al., 2006; Maas et al., 2013; Zou et al., 2017). Other species often overlooked in IPM programmes are the detritivorous insects that feed on decaying organic matter, including post-harvest crop residues left in the field (i.e. middle species of the detritus chain, Fig. 1). In tropical Asian rice, these insects play a crucial role in 


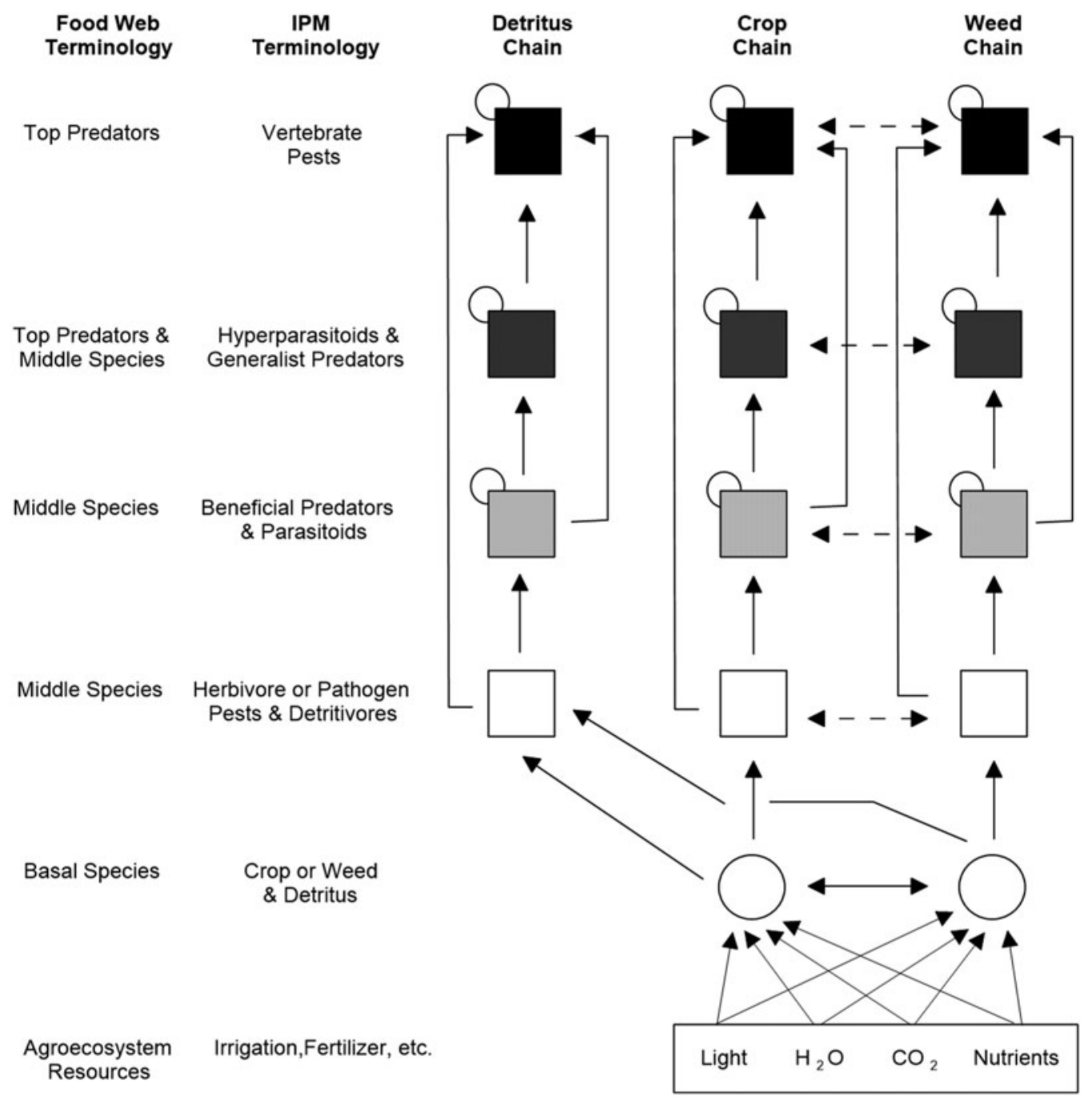

Fig. 1. Simplified interaction web showing energy flow within and between the detritus, crop and weed chains (modified from Norris et al., 2003). Vertical arrows depict trophic links (consumer-prey, omnivory) and horizontal arrows depict non-trophic links (competition, host switching) between members of the crop and weed food chains. A small circle on the top left corner of a secondary consumer box (i.e. middle species or top predator) depicts cannibalism or intraguild predation among its members.

biological control by serving as alternate prey for important generalist predators (e.g. spiders) that regulate potentially damaging insect pests such as the brown planthopper (Settle et al., 1996).

Food webs would have greater application in IPM decision making if dynamics of pest-natural enemy interactions during the cropping cycle were better understood. A good starting point is to compare food webs that have been constructed at several sites on multiple sampling dates using the same set of methods and data organization. At five sites on Luzon, Philippines, Schoenly et al. (1996b) assembled site- and time-specific food webs from a cumulative 687-taxa, 10000 link web of wetland rice and weekly arthropod samples. A site-specific food web accumulates data over different sampling periods (e.g. one crop season) within specified spatial limits, whereas a time-specific web is based on sampling of a single, relatively short time period (e.g. one stage of crop maturity) (Schoenly and Cohen, 1991). At each of the Philippine sites, Schoenly et al. (1996b) found that herbivores increased faster than predators and parasitoids and predators colonized rice earlier than parasitoids. Over the cropping cycle, the potential spider prey and the parasitoids averaged 42 and four taxa, respectively, in the five site webs. However, in the time-specific versions, average ranges of the prey taxa of spiders and the parasitoids dropped to 33-69\% (13-28) and $25-50 \%(2-3)$, respectively, of the site-specific values. Because site-specific webs tend to overestimate numbers of prey per enemy, predators that are identified as polyphagous from site lists may be dismissed prematurely from consideration for biocontrol campaigns. For example, the polyphagy of spiders is one reason why they are less favoured than parasitoids as potential biocontrol agents for many cropping systems (Dent, 2000). Clearly, time-specific webs are more sensitive than site-specific webs in revealing prey or host range of natural enemies and the timing of specific enemy-prey interactions (Schoenly and Cohen, 1991). Similarly, molecular tools (e.g. protein-marking enzyme-linked immunosorbent assay (ELISA), polymerase chain reaction (PCR)-based DNA barcoding) can improve the resolution of food web interactions in agroecosystems (Boyer et al., 2016). Using the ELISA method, for example, Mansfield and Hagler (2016) found that three common insect predators of cotton plantations were also facultative scavengers and that 
scavenging was more prevalent than predation. Building on field observations (Settle et al., 1996), molecular tools have also confirmed early-season predation in agroecosystems, often involving beneficial alternative prey that sustain predators before pest build-up (Athey et al., 2016). Clearly, the agrofoodweb can be used to clarify temporal changes in species interactions. However, understanding and predicting how changing abundances of a resurging pest, for example, influences the remaining members of the community will require manipulative field experiments to identify the mechanisms involved. When combined with path analysis and alternative food-web models (Wootton, 1994), this approach may help reveal the mechanisms by which resurgent pests directly and indirectly affect other species in the agroecosystem, evaluate alternative causal hypotheses and predict which remaining members are strong or weak interactors.

\section{Designing integrated pest management for the living agroecosystem: level III integration}

Any manipulation in the agroecosystem can potentially alter food webs. Application of a fertilizer or pesticide, adoption of a new crop variety, rotation of crops, modification of row-spacing or irrigation schemes, destruction of wild habitat abutting crops and other management practices may cause a shift in the status of one or more pest species and their natural enemies. The application of a pesticide can disrupt the population dynamics of multiple species, reshaping the entire food web (Cohen et al., 1994; Schoenly et al., 1996a). A short-term increase in a fertilizer can significantly modify community structure, trophic interactions and ecosystem function, although the immediate impact may be subtle and unpredictable. Fertilization is known to produce a direct bottom-up impact on the structure and composition of arthropod communities (Wimp et al., 2010). Fertilization may also have an indirect bottom-up impact on natural enemies via enrichment of detritivores, which serve as important food sources for predators in irrigated rice of tropical Asia (Yasumatsu et al., 1979; Settle et al., 1996). Certain nutrients can lead to feedback loops that not only impact detritivores but also ultimately change rates of plant production and decomposition via increasingly greater impacts on natural enemies. In a heavily fertilized crop such as hybrid rice, the detritivores and also natural enemies may especially benefit from the nitrogen input. However, nitrogen also increases the fitness and acceleration of rice pests such as planthoppers ( $\mathrm{Lu}$ and Heong, 2009). Nitrogen-enriched plants can significantly enhance the size, performance and abundance of herbivorous insects (Awmack and Leather, 2002) and increase the potential for outbreaks of pests such as planthoppers in Asian rice (Lu and Heong, 2009).

The IPM strategy should incorporate non-disruptive practices that improve and maintain pest protection, pollination, nutrient cycling, water and soil conservation and other ecosystem services important in subsidizing sustainability of the agroecosystem (Nicholls et al., 2001; Nicholls and Altieri, 2007). A good starting point is to concentrate on the natural factors (biological control agents, native habitat, etc.) and farming practices and inputs (cultivation, crop rotation, crop variety, fertilization, etc.) known to affect the primary pests (plant pathogens, insects, weeds, rodents, etc.) (Smith and van den Bosch, 1967). It is especially important to exploit natural enemies, pest-resistant plants, allelopathy and companion plants that regulate the pests' population growth. These natural agents may require little if any farmer investment and may reduce pesticide costs significantly.
With a reasonable understanding of the natural factors and management practices that operate against the primary pests, IPM specialists can test the IPM strategy on a small scale in representative farming areas - this is how every ecologically based IPM strategy has evolved. For pests that function as metapopulations spread over wide areas (Jervis, 1997; Winder and Woiwood, 2007), the size of their migratory range may dictate the boundary of the agroecosystem to be managed (Apple, 1977). Regardless of the specific manipulations and scale, farmers must understand and accept the IPM strategy as an integral part of the management of their farms or they will resist it.

In larger crop landscapes that vary in degree of habitat fragmentation and isolation, metacommunity theory (Leibold et al., 2004; Holyoak et al., 2005) may hold the key to determining if different farmer practices are compatible with established IPM practices across different spatial scales. Metacommunity theory seeks to identify important processes that generate multi-species patterns at different scales. At small spatial scales, crop field connectivity ensures between-field and between-season exchanges of crop invertebrates and pathogens and bordering vegetation provides year-round refugia for certain pests and their natural enemies. In irrigated rice, local water sources (e.g. irrigation canals, drainage ditches, streams) contain aquatic invertebrates that recolonize rice fields, including predators that eat rice pests (Settle et al., 1996; Schoenly et al., 1998, 2010). At large spatial scales, spatially isolated populations within a metapopulation are linked by dispersal and wind-assisted migration and may explain, for example, how sustained synchronous outbreaks of the brown planthopper occur in different Asian countries (Bottrell and Schoenly, 2012). Large patches of crop fields are more likely to receive immigrants and rescue populations from local extinction (Brown and Kodric-Brown, 1977; Thomas and Jones, 1993). When pests are mobile, successful management may require collective action by neighbouring farmers, particularly when farm sizes are small and close together (Parsa et al., 2014; Coll and Wajnberg, $2017 b$ ), such as in developing countries. Because of their recognizable spatial boundaries, agroecosystems make ideal candidates for testing metacommunity models developed around different assumptions of community assembly, such as patch dynamics, species sorting and mass effects (Baiser et al., 2013).

\section{Taxonomic services}

Accurate identification of pests, natural enemies and other organisms is essential in designing, implementing and sustaining IPM. Because taxonomic services are often inadequate in developing countries (Cock, 2011), farmers may seek unqualified sources for identifying pests and natural enemies, as Heong (2013) found in rice-producing areas of tropical Asia. Various organizations are working to improve and increase taxonomic services in developing countries (Cock, 2011). In addition, DNA barcoding, which uses specific gene tags (or barcodes) to distinguish one species from another (Hebert and Gregory, 2005; Savolainen et al., 2005), could eventually have potential in improving identification services in IPM and other agricultural applications (Cock, 2011). The Barcode of Life Data System (BOLD, htttp://www.boldsystems.org) provides informatics tools and databases in support of researchers building libraries of DNA barcodes. However, DNA barcoding is no substitute for conventional taxonomy. It should be used alongside conventional taxonomy and alternative forms of molecular systematics so errors in identification can be detected. Considerable research investment is required before 
the taxonomic method has practical value in improving identification services in resource-limited agricultural areas. However, it has the potential to provide standardized and high-tech identification tools to large communities of end-users (Savolainen et al., 2005) including extension workers helping farmers to identify pests and natural enemies.

Apps for smartphones and other hand-held devices are being used in many areas to identify various groups of animals and plants and to collect, analyse and store complex ecological information (Teacher et al., 2013). Apps for birdwatchers such as The Sibley eGuide to the Birds of North America (http://www.sibleyguides.com/about/the-sibley-eguide-to-birds-app/) are packed with detailed information for identifying individual species of birds (photos, key traits for identification, flight patterns, habitat, range maps and song clips). A real-time, online checklist programme, eBird (http://www.ebird.org) has revolutionized the way the global birding community reports and accesses information about birds (Wood et al., 2011). Launched in 2002 by the Cornell University Lab of Ornithology and National Audubon Society, eBird provides rich data sources for basic information on bird abundance and distribution at a variety of spatial and temporal scales. Apps designed to help farmers, extension agents and researchers identify crop pests and natural enemies in designated areas and to connect them with and provide input to a realtime checklist, modelled after eBird, should have tremendous value in resource-limited agricultural areas.

\section{Sustaining the integrated pest management effort}

Even the most scientifically, socially and economically viable IPM strategy sensibly designed to meet the needs of a given population of farmers will fail unless provisions are made to enable and sustain its adoption. Farmer networks can provide farmers access to essential information and also boost their confidence in alternative practices. Validation from peers can be a strong motivator for adopting an innovation (Rogers, 1983). Developing country respondents in the Parsa et al. (2014) survey emphasized this point, rating 'IPM requires collective action within a farming community' as the top obstacle facing IPM adoption.

A primary feature of the highly publicized multi-country FAO-IPM programme launched in tropical rice of Asia in 1980 was to link communities of farmers together in 'farmer field schools' (FFS) to learn how to use IPM on their farms. With technical assistance from the Food and Agriculture Organization of the United Nations (FAO), the programme eventually included 13 countries from South and Southeast Asia (Matteson et al., 1994; Gallagher et al., 2009). The FFS gave farmers first-hand experience with IPM practices and ecological concepts and organized farmer networks to implement rice IPM in rural communities of participating countries. The trained farmers reduced insecticide use by $50-80 \%$ while sustaining or increasing rice yield (Matteson, 2000). By reducing insecticides, the FAO-IPM programme averted insecticide-induced outbreaks of the brown planthopper that had plagued rice in much of the region. In Indonesia, more than 1.1 million farmers received IPM training in more than 48000 field schools taught by over 30000 facilitators and trainers (Braun et al., 2006). Training, combined with pesticide regulations, reduced insecticide use by $75 \%$ on rice of IPM-trained farmers in the province of Java (Gallagher et al., 1994). Encouraged by results of the FAO-IPM FFS in Asian rice, the FAO and national programmes expanded FFS training to additional crops and geographical areas. Some 4 million farmers in $>70$ countries had received training when Braun et al. (2006) reviewed the FFS programmes. Braun et al. (2006) concluded that the FFS had a 'consistently positive picture of short- and medium-term impact, with farmers able to improve their agricultural productivity and to increase their leadership role in community-based activities'.

\section{Opposing market forces}

Gains from the FAO-IPM programme for rice diminished after donors ceased its funding in 1999 and national programmes were unable to sustain the effort. Insecticides resurfaced as the primary means for controlling rice insect pests and devastating planthopper outbreaks occurred in areas that had benefitted from the FAO-IPM programme (Heong and Hardy, 2009; Bottrell and Schoenly, 2012; Thorburn, 2014). Heong (2013) chronicled how pesticide marketing disrupted IPM in eight of those countries after the programme stopped. General merchandise retailers in rice-producing areas supplied $50-90 \%$ of the insecticides and also advised farmers on their use. Of the farmers surveyed, $20-80 \%$ relied on insecticide dealers for pest management information and insecticide recommendations. To entice farmers to buy the chemicals, some retailers offered incentives such as cash rewards, lottery tickets, bonus points and holiday trips. Some government workers earned income from chemical companies by promoting their products (Heong, 2013). Hamburger (2002) reported that agricultural extension agents in China generated most of their salaries and office operating costs from pesticide sales. Decades earlier, Brader (1979) emphasized that the lack of an effective independent extension service de-linked from the pesticide industry was a major obstacle preventing wider adoption of integrated pest control in developing countries.

Pesticide marketing forces present particularly difficult challenges in countries lacking effective pesticide education programmes, laws and enforcement procedures (Ecobichon, 2001). Government and non-governmental organization (NGO) IPM projects have helped substantially in implementing IPM and dissuading farmers from using pesticides unnecessarily and unsafely. However, unless the special projects are allied with effective local extension services de-linked from pesticide marketing, pesticide suppliers may prevail as the farmers' chief source of information on crop protection.

\section{Reality of developing country extension services}

According to Anderson and Feder (2007), there were approximately 500000 agricultural extension personnel worldwide in 2005 , with $>90 \%$ of them located in developing countries. Developing countries vary widely in the ratio of farmers per public extension agent (Table 3, data from Davis et al., 2010). It has been reported that India's extension services, on average, reach only about 7\% of the country's farmers (GFRAS, 2012). An estimated $17 \%$ of the Indian farmers received agriculture-related information from other farmers and 13\% from input (e.g. pesticide or fertilizer) dealers. Without proper training in IPM and a continuing source of relevant information, public service agents may not be qualified to provide effective technical assistance in IPM (Peshin et al., 2014). Even if properly trained, the public agents may play a subservient role in areas where pesticide dealers have aggressive marketing (Heong, 2013). Inadequate funding is a major factor hampering public extension efforts to boost IPM in 
Table 3. Ratio of farmers per public extension agent in selected developing countries (Davis et al., 2010)

\begin{tabular}{lcl}
\hline & Total no. agents (1000s) & Agent: Farmers \\
\hline Ethiopia & 45 & $1: 635$ \\
\hline China & 700 & $1: 714$ \\
\hline Indonesia & 54 & $1: 909$ \\
\hline Tanzania & 7 & $1: 2500$ \\
\hline Nigeria & 5 & $1: 3333$ \\
\hline India & 60 & $1: 5000$ \\
\hline
\end{tabular}

resource-limited areas. Until national governments create policies and allocate funding sources to enact IPM, its long-term success is doubtful. Without these actions, as clearly illustrated when the FAO-IPM intercountry programme in tropical Asian rice terminated, farmers are likely to rely exclusively on pesticides and often apply them indiscriminately.

Women comprise $\geqslant 40 \%$ of the agricultural labour force in developing countries (GFRAS, 2012). Yet only about $15 \%$ of the world's extension agents are women and only about $5 \%$ of women farmers benefit from extension services. This gender disparity reduces opportunities for women to adopt IPM and other innovations and to create sustainable livelihoods (GFRAS 2012).

Krell et al. (2016) proposed partnerships between public extension and private industry with shared responsibilities for providing information and technical assistance to farmers. Partnerships between public extension and a company selling pesticide products, for example, may pan out satisfactorily in some situations in developed countries. However, such partnerships would be highly questionable in developing countries that lack the means to guard against unscrupulous marketing practices by pesticide dealers. A major need in those countries is an effective independent extension service, de-linked completely from pesticide merchandizing, as Brader's (1979) review highlighted and the survey of Parsa et al. (2014) re-emphasized.

\section{Innovations in training and outreach}

Providing IPM information and technical assistance to large populations of resource-limited farmers requires a 'new way' of doing business. Although the FFS initiated by the FAO trained some 4 million farmers in over 70 countries (Braun et al., 2006), they included $<2 \%$ of the estimated 280 million farms from low income and lower-middle income countries (data from Appendix A of Lowder et al., 2016). Of the estimated 280 million resource-limited farms, $77 \%$ are in Asia, $17 \%$ in subSaharan Africa, 3\% in the Middle East and North Africa and $1 \%$ in Latin America and the Caribbean (Lowder et al., 2016).

Innovative dissemination networks that convey information electronically via mobile phones and other mobile devices have considerable potential to reach vast numbers of farmers. Although initial adopters were primarily affluent, urban and more educated consumers, in recent years, mobile phones have been adopted by rural and urban consumers in the world's poorest countries, due in part to the introduction of lower-priced handsets and airtime cards (Aker and Mbiti, 2010). Mobile apps for agriculture and rural development are now used commonly in developing countries (Qiang et al., 2011) and some are related to IPM (Shen et al., 2012). In some areas of India, farmers using mobile apps can access real-time data about weather, local markets, seeds, fertilizers, etc. and get guidance from agricultural experts. As Internet connectivity and mobile phone usage become more affordable, the reach is expected to expand to the remotest areas of India (Mittal and Mehar, 2012). Zhang et al. (2016) reported that $3 \mathrm{G}$ network coverage in rural areas of China in 2012 had reached 70\%, the number of smartphones increased by $>30 \%$ per year in the rural market and rural Internet users increased to 146 million with $60 \%$ using smartphones.

Cheaper and wider access to broadband in developing countries should greatly expand the opportunities for designing mobile apps that convey information on IPM for specific crops in designated areas. Using eBird (http://www.ebird.org) as a reference, the apps could become important crowdsourcing tools (Dickinson et al., 2010) for alerting farmers, extension workers and research scientists about emerging problems and also for pinpointing needs for technical assistance in given areas. For example, the mobile device's built-in GPS could identify the location of an extension agent reporting the detection of a new invasive pest. The submitted report along with a photo of the invasive pest could be disseminated quickly to other extension workers, researchers and farmers in the affected area. Regardless of the innovations employed, networks must be designed to meet the specific needs of vast numbers of farmers in resource-limited areas. Training technical specialists in those areas is also needed. Offering IPM training, pest and natural enemy identification, etc. through open access platforms that offer online courses or workshops may have considerable potential when on-site, hands-on training is not possible.

However, the point that Deichmann et al. (2016) made about digital technology should be underscored: '...technology can always only address some, but not all of the barriers faced by farmers in poorer countries'. This caveat applies to web-based training, mobile apps, DNA barcoding and other technological innovations designed to help users in resource-limited agricultural areas. Conventional extension and education programmes have played and will continue to play an invaluable role in enabling farmers to take up innovations, improve production and protect the environment (GFRAS, 2012).

\section{Discussion}

Stern et al. (1959) had an unparalleled impact, stimulating innovations in multi-tactical crop protection and moulding the conceptual basis for modern IPM worldwide. The authors' ecological foundation for integrated crop protection is as valid today as it was in 1959. Moreover, IPM offers potentially the best path to crop protection that increases and sustains agricultural productivity while minimizing threats to humans and the environment. Farmer associations, environmental organizations, national governments, international research and education enterprises and the agroindustry worldwide have recognized the advantages of IPM. Why, then, has the adoption rate been disappointing in developing countries and why, in those situations where IPM was adopted but abandoned, were the farmers unable or unwilling to sustain it?

Morse and Buhler (1997) concluded perceptively that, while IPM can work under certain conditions in developing countries, the situation of most developing farmers does not match the necessary criteria that IPM specialists expect for its implementation. The authors emphasized that the focus should be to determine what is achievable under the farmers' circumstances rather 
than what is technically perfect. The current review has focused on what Morse and Buhler (1997) would probably call 'technically perfect' IPM. The technical features that make IPM function efficiently and help sustainable agriculture succeed in resourcelimited farming areas have been highlighted. However, the current authors agree completely with Morse and Buhler (1997) that IPM will not be adopted and sustained unless it is designed to conform to the farmers' circumstances.

\section{Determining compatibility and farmer acceptance of integrated pest management tactics}

Referring to a multi-tactical crop protection programme as 'IPM' without first verifying compatibility of the tactics and their combined effects on crop yields and farmer profits compared to their singular effects is 'false labelling'. Combining tactics to achieve the best long-term results requires considerable ecological finesse (Thomas, 1999). Researchers must devise inventive experimental designs to disentangle the complicated mix of possible outcomes before the technical compatibility of the different tactics is known. Much more difficult is determining if farmers will accept and sustain the IPM strategy. The most technically sound strategy will not endure if it fails to adjust to local cultures, politics and opposing market forces. Quoting Levins (2007), 'The ultimate goal of IPM is not the pest, or even the crop, but the viability of rural life as a whole and a safe, sustainable food supply in the face of many kinds and increasing intensity of uncertainty'. Researchers can determine, albeit with difficulty, if the IPM tactics are technically compatible. However, whether the IPM system survives is at the mercy of the farmers and local cultures. Efforts to determine the compatibility and efficiency of IPM tactics are merely academic exercises unless farmers and local communities are the central focus.

\section{Integrated pest management requires a landscape perspective}

To achieve its greatest potential in resource-limited agriculture, IPM should evolve from a total landscape view, considering the effects of farm size, neighbouring crops, wild vegetation and aquatic systems. Designing IPM programmes around a landscape perspective provides both opportunities and challenges for innovations such as the 'push-pull' strategy in Africa for cereal crops (Khan et al., 2016) and the planting of nectar-rich companion plants in monocultures of rice in Asia (Gurr et al., 2016). Once farmers understand the interchange of pests and natural enemies among the different vegetation units, they may be willing to modify the vegetation mix (different plant species or different genetic forms of one crop species) in ways that IPM specialists have found to reduce pests and enhance natural enemies. However, to re-emphasize Morse and Buhler's (1997) argument, the focus should be to determine what is achievable under the farmers' circumstances rather than what is technically perfect.

Donor funding for IPM projects in developing countries has usually focused on a single crop such as rice, cotton, or maize. Given existing knowledge about pest and natural enemy interchange among different crops, projects that approach IPM from a total crop landscape perspective with all crops included would be a better investment in many cases. Furthermore, donor funding has given limited attention to the potential of mixing multiline cultivars and different cultivars of the same crop species as an IPM strategy. The approach has considerable promise for managing certain diseases of small grains (Browning et al., 1977;
Mundt, 2002). However, its potential for managing insect and other pests of small grains or other crops is generally unknown.

\section{Common ground for integrated pest management, sustainable} agriculture and conservation biology

Increasing and sustaining agricultural productivity for the growing global population rests heavily on agrobiodiversity at the genetic, population, community, ecosystem and landscape levels. Integrated pest management specialists and sustainable agriculture specialists share an interest in understanding, enhancing and preserving agrobiodiversity. Together and separately, the two groups have made valuable contributions measuring the effects of agricultural practices (e.g. fertilizers, pesticides, cultivar selection, crop rotation, crop plant density, irrigation, cultivation, harvest practices) on pests, natural enemies, pollinators, $\mathrm{N}$-producing microbes and other organisms. Some progress has been made unravelling food webs in selected cropping systems to provide useful insights about interactions of the crop plants, pests and natural enemies and to pinpoint functional traits that different species perform in the agroecosystem (Neuenschwander et al., 1987; Cohen et al., 1994). An important next step is to integrate food web structure with community dynamics, using interaction strength as the conduit (Berlow et al., 2004) and molecular methods as fine tools (Boyer et al., 2016), to clarify how crop food webs change over time and space, particularly in response to introduced species, farming practices, genetic technology and climate change.

The functional traits of species may influence ecosystems directly (e.g. pollination, predation, parasitism, herbivory, competition) or indirectly through responses to local environmental changes such as microclimate or human disturbances (Chapin et al., 2000). Understanding linkages between agrobiodiversity and ecosystem services are crucial for predicting how changes in environment and management practices will impact the multiple ecosystem services essential for increasing and sustaining crop yields (Zhang et al., 2007; Power, 2010; Kremen and Miles, 2012; Wood et al., 2015). Wood et al. (2015) outlined a seven-step trait-based approach leading to the development of farm management strategies that provide multiple ecosystem services. The proposed work would culminate in quantitative models that generate target distributions of species based on their functional traits and identify management strategies that achieve specific ecosystem services.

Identifying and augmenting the species responsible for ecosystem services in resource-limited agriculture will require the collective expertise of IPM and sustainable agriculture specialists. Conservation biologists can also play an important role through collaborative research aimed at conserving key species that provide essential ecosystem services (Paul and Robertson, 1989; Gall and Orians, 1992; Miller and Rossman, 1995; O’Malley, 1999). The work will also require a boosted effort in taxonomic services (conventional and DNA-based methods) to identify species responsible for ecosystem functions. In addition to research benefits of the union, the cooperation of IPM and sustainable agriculture specialists and conservation biologists would bolster the taxonomic capability required for agrobiodiversity surveys.

\section{Can integrated pest management turn the pesticide tide?}

Globally, pesticide use has increased over the last several decades; however, crop losses have not significantly decreased over the 
same period (Oerke, 2006). The United Nations (2017) reported that $65 \%$ of global pesticide sales are controlled by only three companies, made possible through recent mergers involving Monsanto and Bayer, Dow and Dupont and Syngenta and ChemChina. Recent trends suggest that pesticides are increasing in many developing countries. Pesticide imports into Southeast Asian countries, for example, increased nearly sevenfold in value between 1990 and 2010 (FAO data, cited in Normile, 2013). Often, developing countries import formulated pesticides or their active ingredients that have been banned, severely restricted or never patented in nations of origin because of environmental or health concerns (Ecobichon, 2001). Developing countries may have pesticide laws but resources to enforce them and to train farmers on the safe and efficient use of pesticides are usually inadequate.

Stern et al. (1959) envisioned IPM, not as a way to eliminate insecticides but to reconcile insecticide applications with biological control. However, they and other early IPM pioneers emphasized that pesticide applications were corrective measures to be used as a last line of defence after the non-chemical primary management components failed to keep the pests at nondamaging levels. That view is diametrically opposed by today's policymakers of the three major scientific professional societies involved with pest management in the USA - the Weed Science Society of America (WSSA), American Phytopathological Society (APS) and Entomological Society of America (ESA). The WSSA-APS-ESA policy statement rejects the notion that pesticides should be used 'as a last resort' in IPM (http://www. entsoc.org/press-releases/issues-associated-least-toxic-pesticidesapplied-last-resort). Coll and Wajnberg (2017b) argued that this statement ignores the extensive research, regulatory, educational and stewardship efforts that make important pesticide tools available and define their proper and safe use in Integrated Pest Management programmes'.

Parallel with increased use of pesticides in developing countries is the proliferation of genetically engineered (GE) crops with 'pesticide' genes. Of the 26 countries planting GE crops in 2016, 19 were developing countries and seven were industrial countries (ISAAA, 2016). Developing countries grew 99.6 million hectares of GE crops, compared with 85.5 million hectares grown by industrial countries (ISAAA, 2016). Millions of hectares are now planted to GE Bt crops (Tabashnik, 1994).

Some view GE crops as indispensable for future food security (Leyser, 2014). Others are less optimistic about their potential for increasing crop yield (Sinclair et al., 2004). Ecologists have been concerned that the GE crop plants may cause ecological disruptions by killing non-target pests (Romeis et al., 2008); hybridizing with wild relatives and thereby modifying the relatives' natural gene pool (Pilson and Prendeville, 2004); producing weedy, exotic-like hybrids (Pilson and Prendeville, 2004); or by accelerating the rate at which pests evolve strains that defy the resistance traits (Tabashnik, 1994; Gould, 1998; Pilson and Prendeville, 2004). These and other concerns have received substantial research in developed countries but much less in developing countries. Researchers in developing countries have considerable work ahead before the yield potential of the GE crops is known and their ecological effects (in agroecosystems and in communities of nearby wild habitats) are realized. Ecologists and IPM specialists working with sustainable agricultural specialists and local farmers can play an important role by determining if, when and how to integrate $B t$-crops and other engineered crops with pest control genes into IPM systems in resource-limited areas.

\section{Reaching the vast population of resource-limited farmers}

According to Lowder et al. (2016), half of the world's estimated 570 million farms are in developing countries (i.e. low income plus lower-middle income countries). About three-quarters of the farms in low- and lower-middle income countries are smaller than 2 ha, occupy about $30-40 \%$ of the land and have decreased in size from 1960 to 2000 (Lowder et al., 2016). Farmer field schools, media campaigns and other training and outreach efforts have proven effective in familiarizing resource-limited farmers with IPM and encouraging them to adopt it. However, such efforts are expensive and can be expected to reach only a tiny portion of the hundreds of millions of resource-limited farmers. In Senegal, Witt et al. (2008) showed that small proportions of IPM-trained farmers in dispersed villages are insufficient to spread changes outward to other farmers. A critical mass of trained farmers spread among nearby villages is required before information is disseminated effectively and adopted by nonparticipating farmers (Witt et al., 2008).

Special projects like the FAO-IPM programme for rice in South and Southeast Asia make a big swath during the funding period. However, once farmers are disconnected from reliable and continuing sources of IPM information, chemical companies may be quick to fill the gaps, as illustrated when funding for the FAO-IPM programme ceased. What needs to be done to ensure that farmers have the support needed to adopt and sustain a practical and profitable system of IPM? This is the foremost question facing advancement of IPM in developing countries. Meeting the challenge is a huge undertaking. Coll and Wajnberg (2017c) argued persuasively, and used case history examples to support their argument, that government commitment is critical for the sustainable deployment of environmental pest management. Obviously, international donors, research centres, NGOs and farmer associations are also critical actors. Launching a long-term sustainable approach requires the collective input of IPM extension, education and research specialists and specialists in information technology, media development, crowdsourcing, rural sociology, government policy and regulations, etc. Broadband applications using mobile devices will become increasingly important in disseminating IPM information and connecting communities of farmers, extension workers and researchers. Relative to the revolution in biotechnology, Fischer et al. (2009) argued that the potential of information and communication technologies to boost productivity and contribute to more sustainable production systems has received too little attention. As emphasized in the current review, the educational and outreach programmes must be tailored to meet the farmers' circumstances in a given location. The farmers currently face many kinds of uncertainties that affect their perceptions about pests and ways to deal with them. Climate change, the appearance of invasive species, the emergence of pesticide resistance and introductions of new technology such as GE crops intensify the uncertainties and increase pressure to produce higher yields. Therefore, the best support system, regardless of the form it takes, is one that gives farmers confidence that IPM will enhance yields and profits and reduce risks to themselves and the environment in light of the many uncertainties and challenges.

\section{Conclusions}

(1) Stern et al. (1959) influenced the direction of multi-tactical crop protection worldwide and moulded the conceptual basis for modern IPM, which combines various chemical, 
biological and physical control tactics in a cohesive ecologically based pest management scheme. By helping to ensure equitable, secure, sufficient and stable crop protection, IPM is a complementary and necessary feature of sustainable agriculture.

(2) National programmes, farmer associations, international organizations and donors have promoted IPM in resourcelimited areas since the 1970s. IPM has reduced pesticide use and provided more durable crop protection on a range of food and cash crops. However, its adoption rate by developing country farmers has been low and its advances short lived.

(3) The conceptual basis of IPM and the criteria for determining if its control tactics have been integrated harmoniously have been reviewed and it has been shown how local and regional landscape patterns affect pests and influence the design of IPM. It is argued that the agroecosystem must be understood and managed as a living system from a landscape perspective with the goal of enhancing and conserving agrobiodiversity and keeping ecosystem services intact. The obstacles hindering IPM's adoption and sustainment on resource-limited farms in developing countries were discussed and pathways for overcoming them presented.

(4) Despite its low adoption rate in developing countries, IPM potentially offers the best route to economically efficient crop protection that increases and maintains farm productivity while minimizing threats to humans and the environment. Increasing and sustaining wider adoption will require significant investment in research, extension and policy innovations. Closer cooperation between IPM, sustainable agriculture and other specialists would synergize efforts to identify the functional traits of agrobiodiversity that provide essential ecosystem services for increased agricultural productivity and to map out farm management strategies for effectively augmenting these services.

(5) The overarching challenge is devising communication and support systems that will allow resource-limited farmers to try, adopt and sustain IPM that enhances yields and profits and reduces risks in light of the many uncertainties and challenges they face. Public extension services are not currently equipped to assist the vast population of resource-limited farmers. The farmers often rely on pesticide dealers for information on pest management decisions and may be subject to unscrupulous pesticide marketing practices.

(6) Providing reliable information and supporting hundreds of millions of resource-limited farmers who would potentially benefit from IPM requires the collective input of IPM extension and education specialists and also specialists in information technology, media development, crowdsourcing, rural sociology, government policy, etc. The current authors advocate the use of information technology (e.g. broadband apps for smartphones), media development, crowdsourcing and rural sociology to connect farmers to the technical sources. Regardless of the communication medium, the educational and outreach programmes need to be tailored to meet the farmers' circumstances in a given location.

Acknowledgements. DGB is grateful to the University of Maryland libraries for assistance in providing published literature. He is also grateful to the many graduate students in his University's Master of Chemical and Life Sciences online course in biodiversity and conservation biology, which he taught yearly from 2000 to 2015, for sharing valuable insights into species interactions in managed tropical systems. KGS is grateful to Joel E. Cohen for introducing him to the IRRI food web in 1989, Deborah Childers and Julie Reuben, librarians of the California State University, Stanislaus, for assistance in securing published literature used in this review and CSU-Stanislaus for providing sabbatical support in the Spring 2015.

Financial support. DGB received no funding for the work. KGS received initial support for this work from CSU-Stanislaus in the form of a university sabbatical in Spring 2015.

Conflicts of interest. None.

Ethical standards. Not applicable.

\section{References}

Abrol DP (ed.) (2014) Integrated Pest Management: Current Concepts and Ecological Perspective. San Diego, California: Academic Press.

Abrol DP and Shankar U (eds) (2012) Integrated Pest Management: Principles and Practices. Wallingford, Oxfordshire, UK: CABI.

Aker JC and Mbiti IM (2010) Mobile phones and economic development in Africa. Journal of Economic Perspectives 24, 207-232.

Anderson JR and Feder G (2007) Agricultural extension. In Evenson R and Pingali P (eds), Handbook of Agricultural Economics, Volume 3: Agricultural Development: Farmers, Farm Production and Farm Markets. The Netherlands: Elsevier, pp. 2343-2378.

Andow DA (1983) Effects of agricultural diversity on insect populations. In Lockeretz W (ed.), Environmentally Sound Agriculture. New York, New York: Praeger, pp. 91-115.

Andow DA (1991) Vegetational diversity and arthropod population response. Annual Review of Entomology 36, 561-586.

Apple JL (1977) The theory of disease management. In Horsfall JG and Cowling EB (eds), Plant Disease: An Advance Treatise, Vol. I. How Disease is Managed. New York, New York: Academic Press, pp. 79-101.

Arim M and Marquet PA (2004) Intraguild predation: a widespread interaction related to species biology. Ecology Letters 7, 557-564.

Athey KJ, Dreyer J, Kowles KA, Penn HJ, Sitvarin MI and Harwood JD (2016) Spring forward: molecular detection of early season predation in agroecosystems. Food Webs 9, 25-31.

Awmack CS and Leather SR (2002) Host plant quality and fecundity in herbivorous insects. Annual Review of Entomology 47, 817-844.

Baiser B, Buckley HL, Gotelli NJ and Ellison AM (2013) Predicting food-web structure with metacommunity models. Oikos 122, 492-506.

Bambaradeniya CNB, Edirisinghe JP, De Silva DN, Gunatilleke CVS, Ranawana KB and Wijekoon S (2004) Biodiversity associated with an irrigated rice agro-ecosystem in Sri Lanka. Biodiversity and Conservation 13, $1715-1753$.

Barbosa P (1998) Agroecosystems and conservation biological control. In Barbosa P (ed.), Conservation Biological Control. New York, New York: Academic Press, pp. 39-54.

Barfield CS and Swisher ME (1994) Integrated pest management: ready for export? Historical context and internationalization of IPM. Food Reviews International 10, 215-267.

Bearchell SJ, Fraaije BA, Shaw MW and Fitt BDL (2005) Wheat archive links long-term fungal pathogen population dynamics to air pollution. Proceedings of the National Academy of Sciences of the United States of America 102, 5438-5442.

Behan-Pelletier V and Newton G (1999) Computers in biology: linking soil biodiversity and ecosystem function - the taxonomic dilemma. BioScience 49, 149-153.

Berlow EL, Neutel A-M, Cohen JE, De Ruiter PC, Ebenman B, Emmerson M, Fox JW, Jansen VAA, Jones JI, Kokkoris GD, Logofet DO, McKane AJ, Montoya JM and Petchey O (2004) Interaction strengths in food webs: issues and opportunities. Journal of Animal Ecology 73, 585-598.

Bonman JM, Khush GS and Nelson RJ (1992) Breeding rice for resistance to pests. Annual Review of Phytopathology 30, 507-528. 
Bottrell DG (1979) Integrated Pest Management. Council on Environmental Quality. Washington, DC: U.S. Government Printing Office.

Bottrell DG, Barbosa P and Gould F (1998) Manipulating natural enemies by plant variety selection and modification: a realistic strategy? Annual Review of Entomology 43, 347-367.

Bottrell DG and Schoenly KG (2012) Resurrecting the ghost of green revolutions past: the brown planthopper as a recurring threat to high-yielding rice production in tropical Asia. Journal of Asia-Pacific Entomology 15, 122-140.

Bowman WD, Hacker SD and Cain ML (2017) Ecology, 4th Edn. Sunderland, Massachusetts: Sinauer Associates, Inc.

Boyce MS, Haridas CV, Lee CT and NCEAS Stochastic Demography Working Group (2006) Demography in an increasingly variable world. Trends in Ecology and Evolution 21, 141-148.

Boyer S, Snider WE and Wratten SD (2016) Editorial: molecular and isotopic approaches to food webs in agroecosystems. Food Webs 9, 1-3.

Brader L (1979) Integrated pest control in the developing world. Annual Review of Entomology 24, 225-254.

Braun A, Jiggins J, Röling N, van den Berg H and Snijders P (2006) A Global Survey and Review of Farmer Field School Experiences. Report prepared for the International Livestock Research Institute. Wageningen, The Netherlands: ILRI.

Briand F (1983) Environmental control of food web structure. Ecology 64, 253-263.

Brown JH and Kodric-Brown A (1977) Turnover rates in insular biogeography: effect of immigration on extinction. Ecology 58, 445-449.

Browning JA, Simons MD and Torres E (1977) Managing host genes: epidemiologic and genetic concepts. In Horsfall JG and Cowling EB (eds), Plant Disease: An Advance Treatise, Vol. I. How Disease is Managed. New York, New York: Academic Press, pp. 191-212.

Brussaard L, de Ruiter PC and Brown GG (2007) Soil biodiversity for agricultural sustainability. Agriculture, Ecosystems and Environment 121, 233-244.

Cadotte MW, Carscadden K and Mirotchnick N (2011) Beyond species: functional diversity and the maintenance of ecological processes and services. Journal of Applied Ecology 48, 1079-1087.

Chalcraft D and Resetarits WJ (2003) Predator identity and ecological impacts: functional redundancy or functional diversity? Ecology 84, 24072418.

Chapin 3rd FS, Zavaleta ES, Eviner VT, Naylor RL, Vitousek PM, Reynolds HL, Hooper DU, Lavorel S, Sala OE, Hobbie SE, Mack MC and Díaz S (2000) Consequences of changing biodiversity. Nature 405, 234-242.

Chaplin-Kramer R and Kremen C (2012) Pest control experiments show benefits of complexity at landscape and local scales. Ecological Applications 22, 1936-1948.

Chen YH, Langellotto GA, Barrion AT and Cuong NL (2013) Cultivation of domesticated rice alters arthropod biodiversity and community composition. Annals of the Entomological Society of America 106, 100-110.

Chen YH, Gols R and Benrey B (2015) Crop domestication and its impact on naturally selected trophic interactions. Annual Review of Entomology 60, 35-58.

Clark CW (1985) Bioeconomic Modeling and Fisheries Management. New York, New York: Wiley-Interscience.

Cleveland CJ, Betke M, Federico P, Frank JD, Hallam TG, Horn J, López Jr. JD, McCracken GF, Medellín RA, Moreno-Valdez A, Sansone CG, Westbrook JK and Kunz TH (2006) Economic value of the pest control service provided by Brazilian free-tailed bats in southcentral Texas. Frontiers in Ecology and the Environment 4, 238-243.

Cock MJW (2011) Strategic Entry Points for Funding Taxonomic Support to Agriculture in Developing Countries. CABI Working Paper 3. Wallingford, Oxfordshire, UK: CABI.

Cohen JE (1978) Food Webs and Niche Space. Monographs in Population Biology 11. Princeton, New Jersey: Princeton University Press.

Cohen JE, Schoenly K, Heong KL, Justo H, Arida G, Barrion AT and Litsinger JA (1994) A food web approach to evaluating the effect of insecticide spraying on insect pest population dynamics in a Philippine irrigated rice ecosystem. Journal of Applied Ecology 31, 747-763.
Coll M and Bottrell DG (1994) Effects of nonhost plants on an insect herbivore in diverse habitats. Ecology 75, 723-731.

Coll M and Wajnberg E (eds) (2017a) Environmental Pest Management: Challenges for Agronomists, Ecologists, Economists and Policymakers, 1st Edn. New Jersey: John Wiley and Sons Ltd.

Coll $\mathbf{M}$ and Wajnberg E (2017b) Environmental pest management: a call to shift from a pest-centric to a system-centric approach. In Coll $\mathrm{M}$ and Wajnberg E (eds), Environmental Pest Management: Challenges for Agronomists, Ecologists, Economists and Policymakers, 1st Edn. New Jersey: John Wiley and Sons Ltd, pp. 1-17.

Coll $\mathbf{M}$ and Wajnberg E (2017c) Environmental pest management: the need for long-term governmental commitment. In Coll $\mathrm{M}$ and Wajnberg $\mathrm{E}$ (eds), Environmental Pest Management: Challenges for Agronomists, Ecologists, Economists and Policymakers, 1st Edn. New Jersey: John Wiley and Sons Ltd., pp. 407-417.

Conway GR (1993) Sustainable agriculture: the trade-offs with productivity, stability and equitability. In Barbier EB (ed.), Economics and Ecology. Dordrecht, the Netherlands: Springer, pp. 46-65.

Cook SM, Khan ZR and Pickett JA (2007) The use of push-pull strategies in integrated pest management. Annual Review of Entomology 52, 375-400.

Costanza R (1993) Developing ecological research that is relevant for achieving sustainability. Ecological Applications 3, 579-581.

Croft BA (1990) Arthropod Biological Control Agents and Pesticides. New York, New York: Wiley.

Davis K, Swanson B, Amudavi D, Mekonnen DA, Flohrs A, Riese J, Lamb C and Zerfu E (2010) In-depth Assessment of the Public Agricultural Extension System of Ethiopia and Recommendations for Improvement. IFPRI Discussion Paper 01041. Washington, D.C.: International Food Policy Research Institute. Available at https://core.ac.uk/download/pdf/ 6237665.pdf (Accessed 4 May 2018).

Deichmann U, Goyal A and Mishra D (2016) Will digital technologies transform agriculture in developing countries? Agricultural Economics 47(Suppl. 1), 21-33.

de Kraker J (1996) The Potential of Natural Enemies to Suppress Rice Leaffolder Populations (PhD thesis). Wageningen Agricultural University, Wageningen, The Netherlands.

Denison RF (2012) Darwinian Agriculture: How Understanding Evolution Can Improve Agriculture. Princeton, New Jersey: Princeton University Press.

Denison RF, Kiers ET and West SA (2003) Darwinian agriculture: when can humans find solutions beyond the reach of natural selection? The Quarterly Review of Biology 78, 145-168.

Denno RF and Finke DL (2006) Multiple predator interactions and food-web connectance: implications for biological control. In Brodeur J and Boivin G (eds), Trophic and Guild Interactions in Biological Control. Dordrecht, The Netherlands: Springer, pp. 45-70.

Dent D (2000) Insect Pest Management, 2nd Edn. Wallingford, UK: CAB International.

Dickinson JL, Zuckerberg B and Bonter DN (2010) Citizen science as an ecological research tool: challenges and benefits. Annual Review of Ecology, Evolution, and Systematics 41, 149-172.

Ecobichon DJ (2001) Pesticide use in developing countries. Toxicology 160, 27-33.

Ehler LE (2006) Integrated pest management (IPM): definition, historical development and implementation, and the other IPM. Pest Management Science 62, 787-789.

Ehler LE and Bottrell DG (2000) The illusion of integrated pest management. Issues in Science and Technology 16, 61-64.

Ehrlich PR and Daily GC (1993) Science and the management of natural resources. Ecological Applications 3, 558-560.

Fagan WF, Hakim AL, Ariawan H and Yuliyantiningsih S (1998) Interactions between biological control effects and insecticide applications in tropical rice agroecosystems: the potential role of intraguild predation. Biological Control 13, 121-126.

FAO (1975) The Development and Application of Integrated Pest Control in Agriculture. Formulation of a Cooperative Global Programme. Report of an Ad Hoc Session of the FAO Panel of Experts on Integrated Pest Control, Rome, October 15-25, 1974. Rome, Italy: FAO. 
Fischer RA, Byerlee D and Edmeades GO (2009) Can Technology Deliver on the Yield Challenge to 2050? Expert Meeting on How to Feed the World in 2050, Rome, June 24-26, 2009. Rome, Italy: FAO.

Gall GAE and Orians GH (1992) Agriculture and biological conservation. Agriculture, Ecosystems and Environment 42, 1-8.

Gallagher KD, Kenmore PE and Sogawa K (1994) Judicial use of insecticides deter planthopper outbreaks and extend the life of resistant varieties in Southeast Asian rice. In Denno RF and Perfect TJ (eds), Planthoppers: Their Ecology and Management. New York, New York: Chapman and Hall, pp. 599-614.

Gallagher KD, Ooi PAC and Kenmore PE (2009) Impact of IPM programs in asian agriculture. In Peshin $\mathrm{R}$ and Dhawan AK (eds), Integrated Pest Management: Innovation Development Process. The Netherlands: Springer, pp. $347-358$.

Gatto M (1995) Sustainability: is it a well-defined concept? Ecological Applications 5, 1181-1183.

GFRAS (2012) Fact Sheet on Extension Services. Position Paper: June 2012. Lindau, Switzerland: Global Forum for Rural Advisory Services. Available at https://farmingfirst.org/wordpress/wp-content/uploads/2012/06/GlobalForum-for-Rural-Advisory-Services_Fact-Sheet-on-Extension-Services.pdf (Accessed 4 May 2018).

Gliessman SR (2015) Agroecology: The Ecology of Sustainable Food Systems. Boca Raton, Florida: CRC Press.

Goodell PB (2009) Fifty years of the integrated control concept: the role of landscape ecology in IPM in San Joaquin cotton. Pest Management Science 65, 1293-1297.

Gould F (1991) The evolutionary potential of crop pests. American Scientist 79, 496-507.

Gould F (1998) Sustainability of transgenic insecticidal cultivars: integrating pest genetics and ecology. Annual Review of Entomology 43, 701-726.

Gould F, Kennedy GG and Johnson MT (1991) Effects of natural enemies on the rate of herbivore adaptation to resistant host plants. Entomologia Experimentalis et Applicata 58, 1-14.

Gurr GM, Wratten SD and Luna JM (2003) Multi-function agricultural biodiversity: pest management and other benefits. Basic and Applied Ecology 4 107-116.

Gurr GM, Lu Z, Zheng X, Xu H, Zhu P, Chen G, Yao X, Cheng J, Zhu Z, Catindig JL, Villareal S, Chien HV, Cuong LQ, Channoo C, Chengwattana N, Lan LP, Hai LH, Chaiwong J, Nicol HI, Perovic DJ, Wratten SD and Heong KL (2016) Multi-country evidence that crop diversification promotes ecological intensification of agriculture. Nature Plants 2, 16014

Hamburger J (2002) Pesticides in China: a growing threat to food safety, public health and the environment. China Environment Series 5, 29-44.

Hardin MR, Benrey B, Coll M, Lamp WO, Roderick GK and Barbosa P (1995) Arthropod pest resurgence: an overview of potential mechanisms. Crop Protection 14, 3-18.

Hare JD (1992) Effects of plant variation on herbivore-natural enemy interactions. In Fritz RS and Simms EL (eds), Plant Resistance to Herbivores and Pathogens: Ecology, Evolution and Genetics. Chicago, Illinois: University of Chicago Press, pp. 278-298.

Hebert PDN and Gregory TR (2005) The promise of DNA barcoding for taxonomy. Systematic Biology 54, 852-859.

Heckman CW (1979) Rice Field Ecology in Northeastern Thailand: The Effect of Wet and Dry Seasons on a Cultivated Aquatic System. Dordrecht, The Netherlands: Springer Science+Business Media, B. V.

Heinrichs EA and Mochida O (1984) From secondary to major pest status: the case of insecticide-induced rice brown planthopper, Nilaparvata lugens, resurgence. Protection Ecology 7, 201-218.

Heong KL (with Wong, L. and De Los Reyes, J. H.) (2013) Addressing Planthopper Threats to Asian Rice Farming and Food Security: Fixing Insecticide Misuse. ADB Sustainable Manila, Philippines: Asian Development Bank, Development Working Paper Series No. 27.

Heong KL and Hardy B (eds) (2009) Planthoppers: New Threats to the Sustainability of Intensive Rice Production Systems in Asia. Los Baños, Philippines: International Rice Research Institute.

Heong KL, Escalada MM, Chien HV and Cuong LQ (2014) Restoration of rice landscape biodiversity by farmers in Vietnam through education and motivation using media. Surveys and Perspectives Integrating Environment and Society (SAPIENS) 7, 2. Available from: https://journals.openedition. org/sapiens/1578 (Accessed 4 May 2018).

Herbold B and Moyle PB (1986) Introduced species and vacant niches. The American Naturalist 128, 751-760.

Holyoak M, Leibold MA, Mouquet NM, Holt RD and Hoopes MF (2005) Metacommunities: a framework for large-scale community ecology. In Holyoak M, Leibold MA and Holt RD (eds), Metacommunities: Spatial Dynamics and Ecological Communities. Chicago, Illinois: University of Chicago Press, pp. 1-31.

Hughes JB, Hellman JJ, Ricketts TH and Bohannan BJM (2001) Counting the uncountable: statistical approaches to estimating microbial diversity. Applied and Environmental Microbiology 67, 4399-4406.

ICIPE (2013) Stories of Our Success: Positive Outcomes from Push-Pull Farming Systems. Nairobi, Kenya: International Centre of Insect Physiology and Ecology. Available at http://www.push-pull.net/farmers_ success.pdf (Accessed 8 May 2018).

ISAAA (2016) Global Status of Commercialized Biotech/GM Crops: 2016. ISAAA Brief 52. Ithaca, New York: International Service for the Acquisition of Agri-Biotech Applications. Available at https://www.isaaa.org/resources/ publications/briefs/52/download/isaaa-brief-52-2016.pdf (Accessed 8 May 2018).

Jenkinson DS (1991) The Rothamsted long-term experiments: are they still of use? Agronomy Journal 83, 2-10.

Jervis MA (1997) Metapopulation dynamics and the control of mobile agricultural pests: fresh insights. International Journal of Pest Management 43, 251-252.

Johnson MT and Gould F (1992) Interaction of genetically engineered host plant resistance and natural enemies of Heliothis virescens (Lepidoptera: Noctuidae) in tobacco. Environmental Entomology 21, 586-597.

Kaplan I and Eubanks MD (2002) Disruption of cotton aphid (Homoptera: Aphididae) - natural enemy dynamics by red imported fire ants (Hymenoptera: Formicidae). Environmental Entomology 31, 1175-1183.

Kareiva P (1983) Influence of vegetation texture on herbivore populations: resource concentration and herbivore movement. In Denno RF and McClure MS (eds), Variable Plants and Herbivores in Natural and Managed Systems. New York, New York: Academic Press, pp. 259-289.

Kenmore PE, Cariño FO, Perez CA, Dyck VA and Gutierrez AP (1984) Population regulation of the rice brown planthopper (Nilaparvata lugens Stål) within rice fields in the Philippines. Journal of Plant Protection in the Tropics 1, 19-37.

Kennedy GG and Gould F (2007) Ecology of natural enemies and genetically engineered host plants. In Kogan M and Jepson P (eds), Perspectives in Ecological Theory and Integrated Pest Management. New York, New York: Cambridge University Press, pp. 269-300.

Khan ZR and Pickett JA (2004) The 'push-pull' strategy for stemborer management: a case study in exploiting biodiversity and chemical ecology. In Gurr GM, Wratten SD and Altieri MA (eds), Ecological Engineering for Pest Management: Advances in Habitat Manipulations for Arthropods. Collingwood, Victoria, Australia: CSIRO Publishing, pp. 155-164.

Khan ZR, Midega CAO, Amudavi DM, Hassanali A and Pickett JA (2008) On-farm evaluation of the 'push-pull' technology for the control of stemborers and striga weed on maize in western Kenya. Field Crops Research 106, 224-233.

Khan ZR, Midega CAO, Hooper A and Pickett JA (2016) Push-pull: chemical ecology-based integrated pest management technology. Journal of Chemical Ecology 42, 689-697.

Knapp RA, Matthews KR and Sarnelle O (2001) Resistance and resilience of alpine lake fauna to fish introductions. Ecological Monographs 71, 401-421.

Knapp RA, Hawkins CP, Ladau J and McClory JG (2005) Fauna of Yosemite National Park lakes has low resistance but high resilience to fish introductions. Ecological Applications 15, 835-847.

Kogan M (1988) Integrated pest management theory and practice. Entomologia Experimentalis et Applicata 49, 59-70.

Kogan M (1998) Integrated pest management: historical perspectives and contemporary developments. Annual Review of Entomology 43, 243-270.

Kogan M and Jepson P (eds) (2007) Perspectives in Ecological Theory and Integrated Pest Management. New York, New York: Cambridge University Press. 
Koul O, Cuperus GW and Elliott N (eds) (2008) Areawide Pest Management: Theory and Implementation. Wallingford, Oxfordshire, UK: Centre for Agriculture and Bioscience International.

Krell RK, Fisher ML and Steffey KL (2016) A proposal for public and private partnership in extension. Journal of Integrated Pest Management 7, 4.

Kremen C and Miles A (2012) Ecosystem services in biologically diversified versus conventional farming systems: benefits, externalities, and trade-offs. Ecology and Society 17, 40. http://dx.doi.org/10.5751/ES-05035-170440.

Landis DA, Wratten SD and Gurr GM (2000) Habitat management to conserve natural enemies of arthropod pests in agriculture. Annual Review of Entomology 45, 175-201.

Lavorel S and Garnier E (2002) Predicting changes in community composition and ecosystem functioning from plant traits: revisiting the Holy Grail. Functional Ecology 16, 545-556.

Leibold MA, Holyoak M, Mouquet N, Amarasekare P, Chase JM, Hoopes MF, Holt RD, Shurin JB, Law R, Tilman D, Loreau M and Gonzalez A (2004) The metacommunity concept: a framework for multiscale community ecology. Ecology Letters 7, 601-613.

Letourneau DK (1998) Conservation biology: lessons for conserving natural enemies. In Barbosa P (ed.), Conservation Biological Control. New York, New York: Academic Press, pp. 9-38.

Letourneau DK, Armbrecht I, Rivera BS, Lerma JM, Carmona EJ, Daza MC, Escobar S, Galindo V, Gutiérrez C, López SD, Mejía JL, Rangel AMA, Rangel JH, Rivera L, Saavedra CA, Torres AM and Trujillo AR (2011) Does plant diversity benefit agroecosystems? A synthetic review. Ecological Applications 21, 9-21.

Levins R (2007) From simple IPM to the management of agroecosystems. In Kogan M and Jepson P (eds), Perspectives in Ecological Theory and Integrated Pest Management. New York, New York: Cambridge University Press, pp. 45-64.

Leyser O (2014) Moving beyond the GM debate. PLoS Biology 12, e1001887. https://doi.org/10.1371/journal.pbio.1001887.

Liu X, Chen M, Collins HL, Onstad DW, Roush RT, Zhang Q, Earle E and Shelton AM (2014) Natural enemies delay insect resistance to Bt crops. PLoS ONE 9, e90366. https://doi.org/10.1371/journal.pone.0090366.

Lowder SK, Skoet J and Raney T (2016) The number, size, and distribution of farms, smallholder farms, and family farms worldwide. World Development $87,16-29$.

Lu Z and Heong KL (2009) Effects of nitrogen-enriched rice plants on ecological fitness of planthoppers. In Heong KL and B. Hardy B (eds), Planthoppers: New Threats to the Sustainability of Intensive Rice Production Systems in Asia. Los Baños, Philippines: International Rice Research Institute, pp. 247-256.

Ludwig D, Hilborn R and Walters C (1993) Uncertainty, resource exploitation, and conservation: lessons from history. Ecological Applications 3, 547-549.

Maas B, Clough Y and Tscharntke T (2013) Bats and birds increase crop yield in tropical agroforestry landscapes. Ecology Letters 16, 1480-1487.

Mansfield S and Hagler JR (2016) Wanted dead or alive: scavenging versus predation by three insect predators. Food Webs 9, 12-17.

Maredia KM, Dakouo D and Mota-Sanchez D (eds) (2003) Integrated Pest Management in the Global Arena. Wallingford, Oxfordshire, UK: Centre for Agriculture and Bioscience International.

Matson PA, Parton WJ, Power AG and Swift MJ (1997) Agricultural intensification and ecosystem properties. Science 277, 504-509.

Matteson PC (2000) Insect pest management in tropical Asian irrigated rice. Annual Review of Entomology 45, 549-574.

Matteson PC, Gallagher KD and Kenmore PE (1994) Extension of integrated pest management for planthoppers in Asian irrigated rice: empowering the user. In Denno RF and Perfect TJ (eds), Planthoppers: Their Ecology and Management. New York, New York: Chapman and Hall, pp. 656-685.

May RM (1976) Patterns in multi-species communities. In May RM (ed.), Theoretical Ecology: Principles and Applications. Philadelphia, Pennsylvania: W. B. Saunders Company, pp. 142-162.

Mittal S and Mehar M (2012) How mobile phones contribute to growth of small farmers? Evidence from India. Quarterly Journal of International Agriculture 51, 227-244.
Miller DR and Rossman AY (1995) Systematics, biodiversity, and agriculture. BioScience 45, 680-686.

Morandin LA and Kremen C (2013) Hedgerow restoration promotes pollinator populations and exports native bees to adjacent fields. Ecological Applications 23, 829-839.

Morin PJ (2011) Community Ecology, 2nd Edn. Oxford, Oxfordshire, UK: Wiley-Blackwell.

Morse S and Buhler W (1997) IPM in developing countries: the danger of an ideal. Integrated Pest Management Reviews 2, 175-185.

Mundt CC (2002) Use of multiline cultivars and cultivar mixtures for disease management. Annual Review of Phytopathology 40, 381-410.

Naeem S and Wright JP (2003) Disentangling biodiversity effects on ecosystem functioning: deriving solutions to a seemingly insurmountable problem. Ecology Letters 6, 567-579.

Nakasuji F and Dyck VA (1984) Evaluation of the role of Microvelia douglasi atrolineata (Bergroth) (Heteroptera: Veliidae) as predator of the brown planthopper, Nilaparvata lugens (Stål) (Homoptera: Delphacidae). Researches on Population Ecology 26, 134-149.

Neuenschwander P, Hennessey RD and Herren HR (1987) Food web insects associated with the cassava mealybug, Phenacoccus manihoti Matile-Ferrero (Hemiptera: Pseudococcidae), and its introduced parasitoid, Epidinocarsis lopezi (DeSantis). Bulletin of Entomological Research 77, 177-189.

Nicholls CI and Altieri MA (2007) Agroecology: contributions towards a renewed ecological foundation for pest management. In Kogan $M$ and Jepson P (eds), Perspectives in Ecological Theory and Integrated Pest Management. New York, New York: Cambridge University Press, pp. 431-468.

Nicholls CI, Parrella MP and Altieri MA (2001) The effects of a vegetational corridor on the abundance and dispersal of insect biodiversity within a northern California organic vineyard. Landscape Ecology 16, 133-146.

Nichols FH, Thompson JK and Schemel LE (1990) Remarkable invasion of San Francisco Bay (California, USA) by the Asian clam Potamocorbula amurensis. II. Displacement of a former community. Marine Ecology Progress Series 66, 95-101.

Nixon R (1972) Special Message to the Congress Outlining the 1972 Environmental Program, February 8, 1972. Online by G. Peters and J. T. Woolley, The American Presidency Project. Available at http://www. presidency.ucsb.edu/ws/?pid=3731 (Accessed 8 May 2018).

Normile D (2013) Vietnam turns back a 'tsunami of pesticides. Science 341, $737-738$

Norris RF (2007) Weed ecology, habitat management and IPM. In Kogan M and Jepson P (eds), Perspectives in Ecological Theory and Integrated Pest Management. New York, New York: Cambridge University Press, pp 361-392.

Norris RF and Kogan M (2000) Interactions between weeds, arthropod pests, and their natural enemies in managed ecosystems. Weed Science 48, 94-158.

Norris RF, Caswell-Chen EP and Kogan M (2003) Concepts in Integrated Pest Management. Upper Saddle River, New Jersey: Prentice-Hall.

Oerke E-C (2006) Crop losses to pests. Journal of Agricultural Science, Cambridge 144, 31-43.

O'Malley RE (1999) Agricultural wetland management for conservation goals: invertebrates in California ricelands. In Batzer DP, Rader RB and Wissinger SA (eds), Invertebrates in Freshwater Wetlands of North America: Ecology and Management. New York, New York: Wiley, pp. 857-885.

Osteen CD and Szmedra PI (1989) Agricultural Pesticide Use Trends and Policy Issues. Agricultural Economic Report No. 622. Washington, DC: Economic Research Service, U.S. Department of Agriculture.

Paine RT (1966) Food web complexity and species diversity. The American Naturalist 100, 65-75.

Paine RT (1969) A note on trophic complexity and community stability. The American Naturalist 103, 91-93.

Parsa S, Morse S, Bonifacio A, Chancellor TCB, Condori B, CrespoPérez V, Hobbs SLA, Kroschel J, Ba MN, Rebaudo F, Sherwood SG, Vanek SJ, Faye E, Herrera MA and Dangles O (2014) Obstacles to integrated pest management adoption in developing countries. Proceedings of the National Academy of Sciences of the United States of America 111, 3889-3894. 
Pathummal Beevi S, Lyla KR and Narendran TC (2000) Hymenopteran diversity in single- and double-cropped rice ecosystems in Kerala, India. International Rice Research Notes 25, 20-21.

Paul EA and Robertson GP (1989) Ecology and the agricultural sciences: a false dichotomy? Ecology 70, 1594-1597.

Perrin RM and Phillips ML (1978) Some effects of mixed cropping on the population dynamics of insect pests. Entomologia Experimentalis et Applicata 24, 585-593.

Peshin R and Dhawan AK (eds) (2009a) Integrated Pest Management, Volume 1: Innovation-Development Process. Dordrecht, The Netherlands: Springer.

Peshin R and Dhawan AK (eds) (2009b) Integrated Pest Management, Volume 2: Dissemination and Impact. Dordrecht, The Netherlands: Springer.

Peshin R, Jayaratne KSU and Sharma R (2014) IPM extension: a global overview. In Abrol DP (ed.), Integrated Pest Management: Current Concepts and Ecological Perspective. San Diego, Calfornia: Academic Press, pp. 493-529.

Philips CR, Rogers MA and Kuhar TP (2014) Understanding farmscapes and their potential for improving IPM programs. Journal of Integrated Pest Management 5, C1-C9. http://dx.doi.org/10.1603/IPM13018.

Pickett CH and Bugg RL (eds) (1998) Enhancing Biological Control: Habitat Management to Promote Natural Enemies of Agricultural Pests. Oakland, California: University of California Press.

Pilson D and Prendeville HR (2004) Ecological effects of transgenic crops and the escape of transgenes into wild populations. Annual Review of Ecology, Evolution, and Systematics 35, 149-174.

Pimentel D (1961) Species diversity and insect population outbreaks. Annals of the Entomological Society of America 54, 76-86.

Pimm SL (1991) The Balance of Nature? Ecological Issues in the Conservation of Species and Communities. Chicago, Illinois: University of Chicago Press.

Polis GA, Myers CA and Holt RD (1989) The ecology and evolution of intraguild predation: potential competitors that eat each other. Annual Review of Ecology, Evolution, and Systematics 20, 297-330.

Poveda K, Gómez MI and Martínez E (2008) Diversification practices: their effect on pest regulation and production. Revista Colombiana Entomología 34, 131-144.

Power AG (1999) Linking ecological sustainability and world food needs. Environment, Development and Sustainability 1, 185-196.

Power AG (2010) Ecosystem services and agriculture: tradeoffs and synergies. Philosophical Transactions of the Royal Society B: Biological Sciences 365, 2959-2971.

Pretty J and Bharucha ZP (2015) Integrated pest management for sustainable intensification of agriculture in Asia and Africa. Insects 6, 152-182.

Prokopy RJ (1993) Stepwise progress toward IPM and sustainable agriculture. IPM Practitioner 15, 1-4.

Prokopy RJ and Croft BA (1994) Apple insect management. In Metcalf RL and Luckmann WH (eds), Introduction to Insect Pest Management, 3rd Edn. New York, New York: Wiley, pp. 543-589.

Qiang CZ, Kuek SC, Dymond A and Esselaar S (2011) Mobile Applications for Agriculture and Rural Development. Washington, DC: ICT Sector Unit, World Bank.

Risch SJ and Carroll CR (1982) Effect of a keystone predaceous ant, Solenopsis geminata, on arthropods in a tropical agroecosystem. Ecology 63, 19791983.

Risch SJ, Andow D and Altieri MA (1983) Agroecosystem diversity and pest control: data, tentative conclusions, and new research directions. Environmental Entomology 12, 625-629.

Rogers EM (1983) Diffusion of Innovations, 4th Edn. New York, New York: The Free Press.

Romeis J, Bartsch D, Bigler F, Candolfi MP, Gielkens MM, Hartley SE, Hellmich RL, Huesing JE, Jepson PC, Layton R, Quemada H, Raybould A, Rose RI, Schiemann J, Sears MK, Shelton AM, Sweet J, Vaituzis Z and Wolt JD (2008) Assessment of risk of insect-resistant transgenic crops to nontarget arthropods. Nature Biotechnology 26, 203-208.

Root RB (1973) Organization of a plant-arthropod association in simple and diverse habitats: the fauna of collards (Brassica oleracea). Ecological Monographs 43, 95-124.

Rosenheim JA, Kaya HK, Ehler LE, Marois JJ and Jaffee BA (1995) Intraguild predation among biological-control agents: theory and evidence. Biological Control 5, 303-335.
Savidge JA (1987) Extinction of an island forest avifauna by an introduced snake. Ecology 68, 660-668.

Savolainen V, Cowan RS, Vogler AP, Roderick GK and Lane R (2005) Towards writing the encyclopaedia of life: an introduction to DNA barcoding. Philosophical Transactions of the Royal Society of London B: Biological Sciences 360, 1805-1811.

Schoenly KG and Barrion AT (2016) Designing standardized and optimized surveys to assess invertebrate biodiversity in tropical irrigated rice using structured inventory and species richness models. Environmental Entomology 45, 446-464.

Schoenly K and Cohen JE (1991) Temporal variation in food web structure: 16 empirical cases. Ecological Monographs 61, 267-298.

Schoenly KG, Cohen JE, Heong KL, Arida GS, Barrion AT and Litsinger JA (1996a) Quantifying the impact of insecticides on food web structure of rice-arthropod populations in a Philippine farmer's irrigated field: a case study. In Polis GA and Winemiller KO (eds), Food Webs: Integration of Patterns and Dynamics. Boston, MA: Springer, pp. 343-351.

Schoenly K, Cohen JE, Heong KL, Litsinger JA, Aquino GB, Barrion AT and Arida G (1996b) Food web dynamics of irrigated rice fields at five elevations in Luzon, Philippines. Bulletin of Entomological Research 86, 451-466.

Schoenly KG, Justo Jr. HD, Barrion AT, Harris MK and Bottrell DG (1998) Analysis of invertebrate biodiversity in a Philippine farmer's irrigated rice field. Environmental Entomology 27, 1125-1136.

Schoenly KG, Cohen JE, Heong KL, Litsinger JA, Barrion AT and Arida GS (2010) Fallowing did not disrupt invertebrate fauna in Philippine lowpesticide irrigated rice fields. Journal of Applied Ecology 47, 593-602.

Sebastian PA, Mathew MJ, Pathummal Beevi S, Joseph J and Biju CR (2005) The spider fauna of the irrigated rice ecosystem in central Kerala, India across different elevational ranges. The Journal of Arachnology 33, 247-255.

Settle WH, Ariawan H, Asuti ET, Cahyana W, Hakim AL, Hindayana D and Lestari AS (1996) Managing tropical rice pests through conservation of generalist natural enemies and alternative prey. Ecology 77, 1975-1988.

Shen Z-R, Cheng D-F, Zhang Y-H and Gao L-W (2012) Role of information and communication technology in integrated pest management. In Abrol DP and Shankar U (eds), Integrated Pest Management: Principles and Practice Wallingford, Oxfordshire, UK: Centre for Agriculture and Biosciences International, pp. 433-449.

Sinclair TR, Purcell LC and Sneller CH (2004) Crop transformation and the challenge to increase yield potential. Trends in Plant Science 9, 70-75.

Smith RF and van den Bosch R (1967) Integrated control. In Kilgore WW and Doutt RL (eds), Pest Control: Biological, Physical, and Selected Chemical Methods. New York, New York: Academic Press, pp. 295-340.

Smukler SM, Sánchez-Moreno S, Fonte SJ, Ferris H, Klonsky K, O'Geen AT, Scow KM, Steenwerth KL and Jackson LE (2010) Biodiversity and multiple ecosystem functions in an organic farmscape. Agriculture, Ecosystems and Environment 139, 80-97.

Stern VM, Smith RF, van den Bosch R and Hagen KS (1959) The integrated control concept. Hilgardia 29, 81-101.

Szczepaniec A, Raupp MJ, Parker RD, Kerns D and Eubanks MD (2013) Neonicotinoid insecticides alter induced defenses and increase susceptibility to spider mites in distantly related crop plants. PLoS ONE 8, e62620. https:// doi.org/10.1371/journal.pone.0062620.

Tabashnik BE (1994) Evolution of resistance to Bacillus thuringiensis. Annual Review of Entomology 39, 47-79.

Tahvanainen JO and Root RB (1972) The influence of vegetational diversity on the population ecology of a specialized herbivore, Phyllotreta cruciferae (Coleoptera: Chrysomelidae). Oecologia 10, 321-346.

Tandon PL (2001) Negative aspects of interaction between host plant resistance and biological control and its implication in integrated pest management of crops. In Upadhyay RK, Mukerji KG and Chamola BP (eds), Biocontrol Potential and its Exploitation in Sustainable Agriculture Volume 2: Insect Pests. New York, New York: Springer, pp. 13-21.

Teacher AGF, Griffiths DJ, Hodgson DJ and Inger R (2013) Smartphones in ecology and evolution: a guide for the apprehensive. Ecology and Evolution 3, 5268-5278.

Thomas MB (1999) Ecological approaches and the development of "truly integrated" pest management. Proceedings of the National Academy of Sciences of the United States of America 96, 5944-5951. 
Thomas CD and Jones TM (1993) Partial recovery of a skipper butterfly (Hesperia comma) from population refuges: lessons for conservation in a fragmented landscape. Journal of Animal Ecology 62, 472-481.

Thorburn C (2014) Empire strikes back: the making and unmaking of Indonesia's national integrated pest management program. Agroecology and Sustainable Food Systems 38, 3-24.

Tilman D and Downing JA (1994) Biodiversity and stability in grasslands. Nature 367, 363-365.

Tilman D, Cassman KG, Matson PA, Naylor R and Polasky S (2002) Agricultural sustainability and intensive production practices. Nature 418, 671-677.

Tomich TP, Brodt S, Ferris H, Galt R, Horwath WR, Kebreab E, Leveau JHJ, Liptzin D, Lubell M, Merel P, Michelmore R, Rosenstock T, Scow K, Six J, Williams N and Yang L (2011) Agroecology: a review from a global change perspective. Annual Review of Environment and Resources 36, 193-222.

Trochim WMK (1989) An introduction to concept mapping for planning and evaluation. Evaluation and Program Planning 12, 1-16.

United Nations (2017) Report of the Special Rapporteur on the Right to Food. Geneva, Switzerland: United Nations Human Rights Office of the High Commission. Available at http://reliefweb.int/report/world/report-specialrapporteur-right-food-ahrc3448 (Accessed 8 May 2018).

van den Bosch R, Messenger PS and Gutierrez AP (1982) An Introduction to Biological Control. New York, New York: Plenum Press.

Vandermeer JH (1989) The Ecology of Intercropping. New York, New York: Cambridge University Press.

Warnert JE (2009) The 50th anniversary of a great idea: landmark Hilgardia article on 'integrated control' considered 'most important' pest control paper of 20th century. California Agriculture 63, 160-161.

Way MJ and van Emden HF (2000) Integrated pest management in practice pathways towards successful application. Crop Protection 19, 81-103.

Wilson AL, Watts RJ and Stevens MM (2008) Effects of different management regimes on aquatic macroinvertebrate diversity in Australian ricefields. Ecological Research 23, 565-572.

Wimp GM, Murphy SM, Finke DL, Huberty AH and Denno RF (2010) Increased primary production shifts the structure and composition of a terrestrial arthropod community. Ecology 91, 3303-3311.
Winder L and Woiwood IP (2007) Populations, metapopulations: elementary units of IPM systems. In Kogan M and Jepson P (eds), Perspectives in Ecological Theory and Integrated Pest Management. New York, New York: Cambridge University Press, pp. 65-86.

Witt R, Pemsl DE and Waibel H (2008) The farmer field school Senegal: does training intensity affect the diffusion of information? Journal of International Agriculture and Extension Education 15, 47-60.

Wood C, Sullivan B, Iliff M, Fink D and Kelling S (2011) Ebird: engaging birders in science and conservation. PLoS Biology 9, e1001220. https://doi. org/10.1371/journal.pbio.1001220.

Wood SA, Karp DS, DeClerck F, Kremen C, Naeem S and Palm CA (2015) Functional traits in agriculture: agrobiodiversity and ecosystem services. Trends in Ecology and Evolution 30, 531-539.

Wootton JT (1994) Predicting direct and indirect effects: an integrated approach using experiments and path-analysis. Ecology 75, 151-165.

Yasumatsu K, Hashimoto and Chang YD (1979) Chironomid fauna of Korea and their role in the rice agroecosystem. International Rice Research Newsletter 4, 17-18.

Yu X, Heong KL, Hu C and Barrion AT (1996) Role of non-rice habitats for conserving egg parasitoids of rice planthoppers and leafhoppers. In Hokyo N and Norton G (eds), Proceedings of the International Workshop on Pest Management Strategies in Asian Monsoon Agroecosystems. Kumamoto, Japan: Kyushu National Agricultural Experiment Station, pp. 63-77.

Zhang W, Ricketts TH, Kreman C, Carney K and Swinton SM (2007) Ecosystem services and dis-services to agriculture. Ecological Economics 64, 253-260.

Zhang Y, Wang L and Duan Y (2016) Agricultural information dissemination using ICTs: a review and analysis of information dissemination models in China. Information Processing in Agriculture 3, 117-129.

Zhu Y, Chen H, Fan J, Wang Y, Li Y, Chen J, Fan J, Yang S, Hu L, Leung H, Mew TW, Teng PS, Wang $Z$ and Mundt CC (2000) Genetic diversity and disease control in rice. Nature 406, 718-722.

Zou Y, de Kraker J, Bianchi FJJA, van Telgen MD, Xiao $\mathrm{H}$ and van der Werf W (2017) Video monitoring of brown planthopper predation in rice shows flaws of sentinel methods. Scientific Reports 7, 42210. 